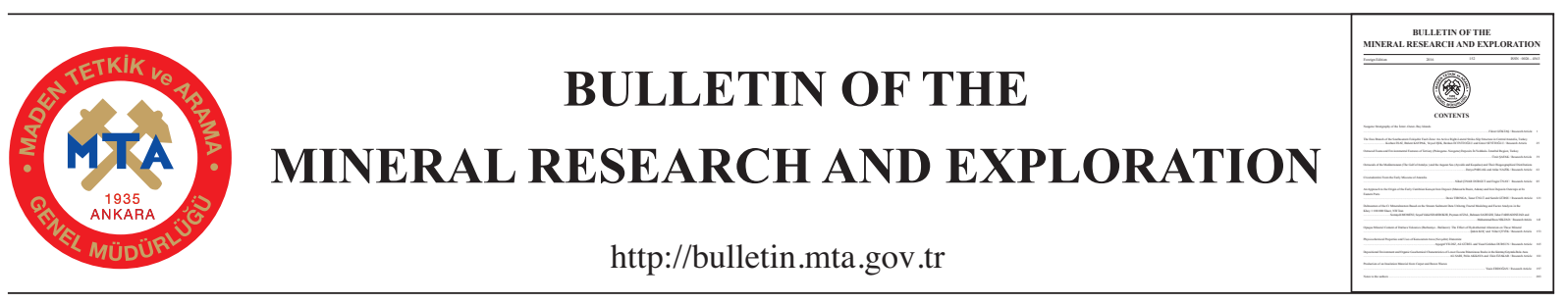

\title{
CRICETODONTINI FROM THE EARLY MIOCENE OF ANATOLIA
}

Nihal ÇINAR DURGUT ${ }^{*}$ and Engin ÜNAY

*Maden Tetkik ve Arama Genel Müdürlüğ̈̈ Jeoloji Etütleri Dairesi, 06520 Ankara, Turkey.

Research Article

Keywords:

Anatolia, Early Miocene,

Rodentia, Cricetodon,

Deperetomys, Taxonomy,

Phylogeny

Received:06.03.2015

Accepted:04.05.2015

\begin{abstract}
Cricetodon and Deperetomys from the early Miocene localities Söke, Dededağ (Aydın), Kınık, Harta (Manisa) Western Anatolia and Yapıntı (İçel) Southern Anatolia are studied. Seven species, four of which are new, are described: Cricetodon trallesensis n. sp., Cricetodon fikreti n. sp., Cricetodon magnesiensis $\mathrm{n}$. sp., Cricetodon yapintiensis n. sp., Cricetodon versteegi, Cricetodon kasapligili and Cricetodon cf. kasapligili, Deperetomys cf. intermedius. In order to establish phylogenetic relations of the Cricetodon species, a cladistic analysis are performed.
\end{abstract}

\section{Introduction}

The Miocene is a significant period of the mammals due to their greatest evolutionary stage. In the early Miocene, Anatolia plays an important role as a bridge for species dispersal between Asia, Europe and North Africa. In this paper, the Cricetodontini which is the first record from Anatolia in early Miocene is studied. The geographical range of the Cricetodontini is quite large, covering Eurasia from Kazakhstan to Portugal and North Africa and China. Its representatives remained in Anatolia during the early Miocene and they occurred in Europe during the latest early Miocene. The tribe was widely extended in Europe in the middle Miocene. Their decline starts in the late Miocene and their extinction is at the beginning of the Pliocene.

The early Miocene Cricetodon and Deperetomys collected from Söke, Dededağ (Aydın), Kınık, Harta (Manisa) and Yapıntı (İçel) (Figure 1) by Fikret Göktaş, Engin Ünay, Gerçek Saraç (General Directorate of Mineral Research and Exploration (MTA), Turkey) and Hans de Bruijn (Utrecht University, The Netherlands) during the MTA geology projects carried out between the years of 1992-2001 are studied. Most of the rodent faunas from these localities have so far only been mentioned in preliminary lists in some internal reports of MTA (Ünay and Göktaş, 1999; 2000; Göktaş and Ünay, 2000) and in an international report (Ünay et al., 2001).

\section{Material and Methods}

The measurements of the teeth were taken with a Leica S8AP0 ocular micrometer (20 micron units). All values are given in $1 \mathrm{~mm}$ units. For easy comparison all the teeth are presented as if they were from the left side. If the original is from the right side the number on the plates has been underlined. The terminology of the parts of check teeth follows Mein and Freudenthal (1971, b) and Reig (1977) (Figure 2).

The photographs were taken with an environmental scanning electron microscope FEI Quanta 400 MK2 at MTA. The images processing was made using Adobe Photoshop software. All the material is stored in the collections of MTA. 


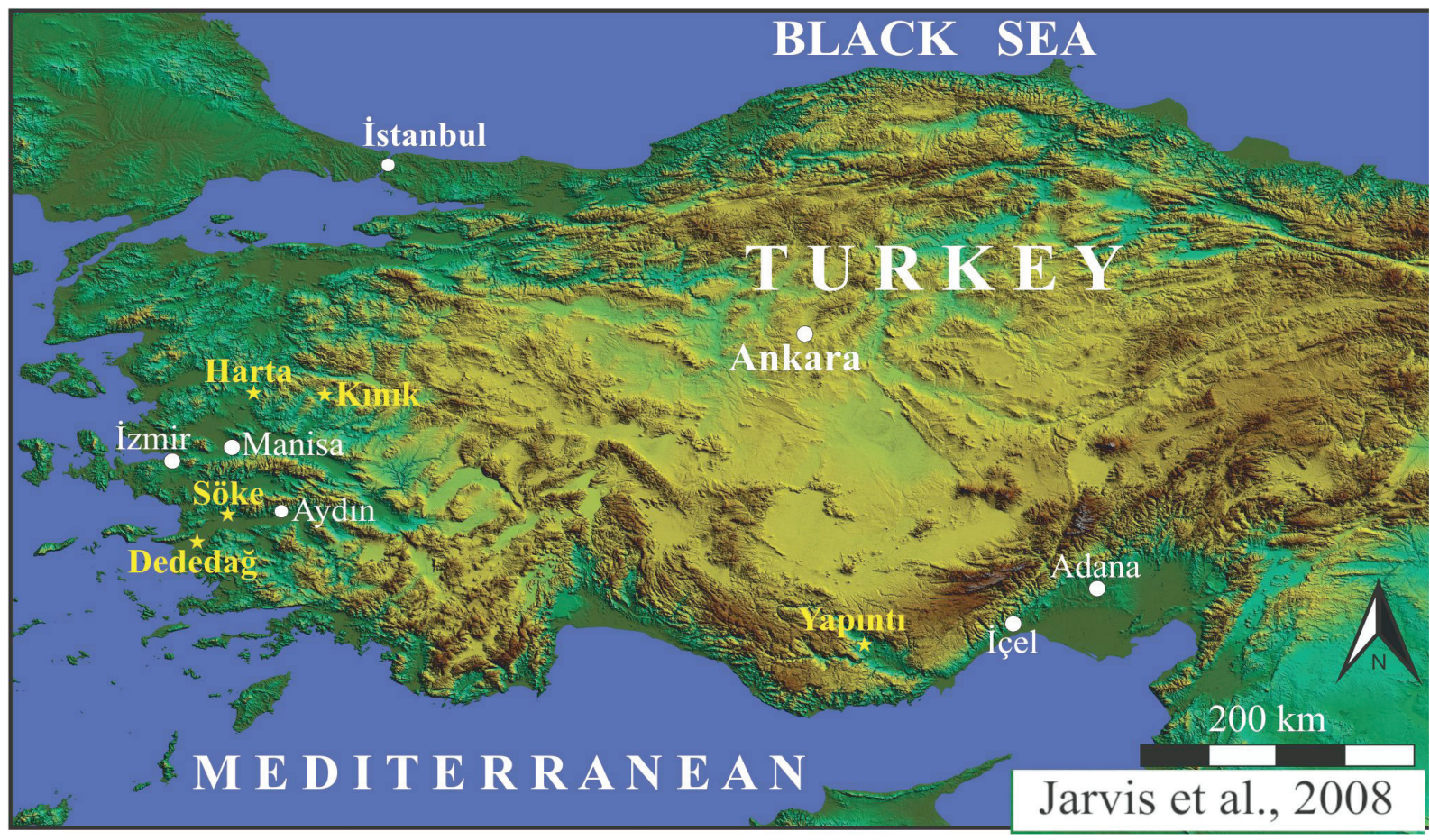

Figure 1- Sketch map of Western and Southern Turkey showing the geographical position of the localities. For the geological setting of the localities the reader is referred to Ünay and Göktaş, 1999; 2000; Göktaş and Ünay, 2000; Ünay et al., 2001

\section{Systematic Paleeontology}

Order: Rodentia Bowdich, 1821

Family: Muridae Illiger, 1811

Tribe: Cricetodontini Simpson, 1945

Genus: Cricetodon Lartet, 1851

Type species: Cricetodon sansaniensis Lartet, 1851

Other species recognized: C. caucaticus Argyropulo, 1938, C. meini Freudenthal, 1963, C.albanensis Mein and Freudenthal, 1971, C. aureus Mein and Freudenthal, 1971, C. jotae Mein and Freudenthal, 1971, C. pasalarensis (Tobien,1978), C. candirensis (Tobien, 1978), C. cariensis (Şen and Ünay, 1979), C. hungaricus (Kordos, 1986), C. aliveriensis Klein Hofmeijer and de Bruijn, 1988, C. versteegi de Bruijn et al., 1993, C. kasapligili de Bruijn et al.,1993, C. tobieni de Bruijn et al., 1993, C. bolligeri Rummel, 1995, C. jumanensis Rummel, 2001, C. engesseri Rummel and Kälin, 2003, C. orientialis Bi, 2005, C. soriae Fernandez et al., 2006, C. klariankae Hir, 2007, C. volkeri Wu, 2009, "C." fandli Prieto et al., 2010, C.wanhei Qiu, 2010, C. nievei López-Guerrero et al., 2014

\section{Cricetodon trallesensis $\mathbf{n} . \mathbf{s p}$.}

(Plate 1)

Type locality: Söke

Age: Early Miocene, MN4 (Ünay and Göktaş, 1999)

Holotype : M1 dext. Nr: SO, 102

Derivatio nominis: The species is named after Tralles, the ancient name of Aydın.

Material and measurements of the Cricetodon trallesensis $\mathrm{n} . \mathrm{sp}$.

\begin{tabular}{|l|c|c|c|c|c|}
\hline \multirow{2}{*}{} & \multicolumn{2}{|c|}{ LENGTH } & \multicolumn{3}{c|}{ WIDTH } \\
\cline { 2 - 6 } & Min-Max & Mean & $\mathrm{N}$ & Min-Max & Mean \\
\hline M1 & $2.43-3.00$ & 2.70 & 52 & $1.65-2.05$ & 1.89 \\
\hline M2 & $1,88-2.25$ & 2.05 & 82 & $1.53-2.00$ & 1.80 \\
\hline M3 & $1.33-1.85$ & 1.54 & 56 & $1.45-1.70$ & 1.56 \\
\hline m1 & $2.03-2.40$ & 2.20 & 51 & $1.45-1.73$ & 1.57 \\
\hline m2 & $1.90-2.35$ & 2.12 & 73 & $1.60-1.93$ & 1.74 \\
\hline m3 & $1.95-2.43$ & 2.10 & 38 & $1.50-1.85$ & 1.63 \\
\hline
\end{tabular}

Diagnosis: The species $C$. trallesensis $\mathrm{n}$. sp. is a medium sized Cricetodon with plump cusps. The rather small anterocone of the M1 is indistinctly divided into two cusps. The labial anterolophule is parallel to the longitidunal ridge. The protolophule and metalophule 


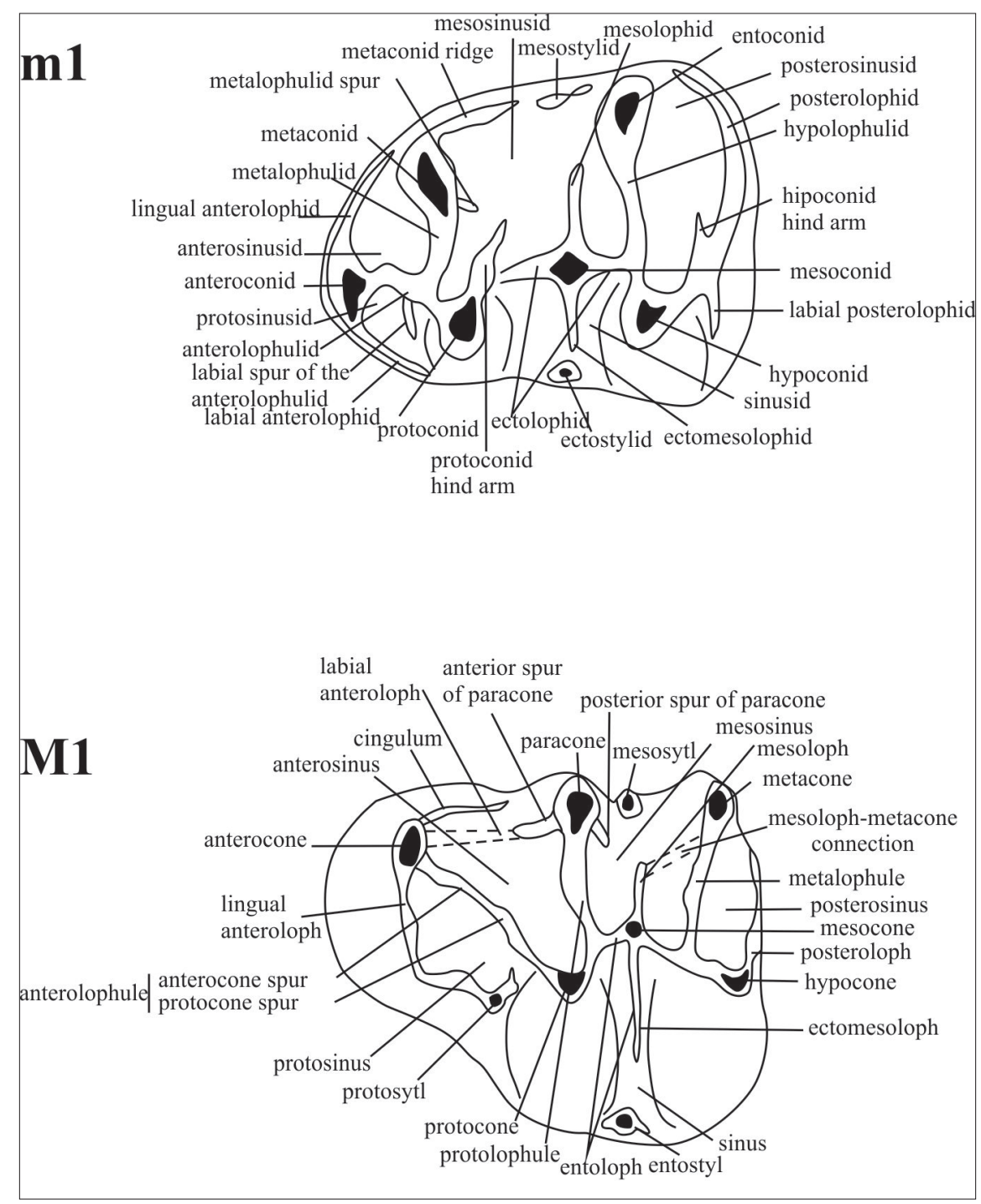

Figure 2- Terminology of the cheek teeth (Mein and Freudenthal (1971b) and Reig (1977))

of the M1 and M2 are parallel and directed posteriorly. The posteroloph does not continue beyond the point where it meets the metalophule. The $\mathrm{m} 1$ has one or two metalophulids. The shape of the M3 maybe rounded or elongated. The M1 and M2 have three or four roots.

Differential Diagnosis: Among the early Miocene cricetodons $C$. trallesensis n. sp. differs from $C$. tobieni from Horlak 1a in having comparatively higher crowned molars, plumber cusps, more elongated M3. Moreover the labial anterolophule in general is parallel to longitudinal ridge in $C$. trallesensis $\mathrm{n}$. sp. whereas it is inclined to the labial edge in C. tobieni. $C$. trallesensis n. sp. differs from C. kasapligili in having more developed labial anterolophule and posterior spur of the paracone in upper molars. The posteroloph connects to the metacone suggesting a more advanced stage of evolution than in C. kasapligili. The molars of $C$. trallesensis n. sp. are larger and rather higher crowned than in C. aliveriensis and C. versteegi.

\section{Description}

M1: The labial outline of the M1 is oblique, not parallel to the lingual border. The anterocone is situated mesio-labially in thirty-three of the fifty-nine specimens and mesially in the others. This tubercule is divided into two equal cusps by an anterior valley that does not extend to the base of the crown so it is single in worn specimens. The labial anterolophule is strong and reaches the base of the paracone in forty two out 
of the fifty five specimens, it is short in nine and absent in four. The lingual anterolophule is absent. There is a transverse spur in the protosinus in twenty-four specimens. The protolophule is directed backwards and connected to the mure behind the protocone. There may be a crest (protolophule I?) on the anterolophule which may connect to the paracone in one specimen. The posterior spur of paracone shows a good deal of variation. It is long reaching to the metalophule in thirty three out of fifty six, short in twenty two and absent in two specimens. The mesoloph is short in fifty specimens and absent in five. The metalophule is directed posteriorly joining the posteroloph at the postero-medial corner of the metacone where the posteroloph also ends. The sinus is inclined anteriorly. The M1 has four roots in six, three in thirty four out of the forty specimens.

M2: The labial and lingual anterolophs are about equally well developed and connect to the paracone and protocone respectively. A weak protolophule I is present in two out of eighty tree specimens only. The protolophule II is transverse or posteriorly directed. The posterior spur of paracone is long reaching the metalophule in twenty three, long but free in forty two, short in sixteen and absent in the two other specimens. A short mesoloph is present in only eight specimens out of sixty eight. The posteriorly directed metalophule is almost parallel to the longitudinal axis. The posteroloph ends where it meets the metalophule. The sinus is transverse or directed anteriorly. The M2 has three roots in forty one and four in five specimens.

M3: The M3 shows a wide variation in outline ranging from the long to short morph types with intermediate. The labial and the lingual branches of the anteroloph are about equally well developed and connect to the paracone and protocone respectively. The protolophule is double in twenty five out of fifty five specimens. The posterior spur of paracone is short or absent. The homology of the mesoloph is not easy to detect in every specimen. It is long and posteriorly directed in the clearly elongated specimens whereas in the median valley of some shorter specimens there is a short labially free, anteriorly directed crest which may join to form a longer crest enclosing an island with protocone. The metalophule is directed posteriorly. The posteroloph reaches the base of the metacone. The sinus is directed anteriorly in elongated specimens and posteriorly in the rounded specimens. The M3 has three roots. m1: The anteroconid is situated on the longitudinal axis of the occlusal surface. The labial anterolophid reaches the base of the protoconid. The lingual anterolophid is weak or absent. The metaconid and the entoconid have a posterior spur. The metalophulid is double in ten out of fifty two specimens. The metalophulid II is directed posteriorly connecting to the posterior part of the protoconid. The mesolophid is short or absent. The hypolophulid is transverse or directed anteriorly connecting to the longitudinal ridge in front of the hypoconid. Most specimens have an ectomesolophid. The hypoconulid is distinct. The wide sinusid is transverse. The $\mathrm{m} 1$ has two strong roots.

m2: The labial anterolophid is quite strong reaching the base of the protoconid. The lingual anterolophid connects to the base of the metaconid in five specimens, short in fourteen and absent in fifty. The metalophulid and hypolophulid are directed anteriorly. The short mesolophid is inclined posteriorly. The posterolophid reaches the base of the entoconid. The wide sinusid is transverse. The $\mathrm{m} 2$ has two strong roots.

m3: The labial anterolophid is rather strong reaching the base of the protoconid. The lingual anterolophid is short or absent. The metalophulid is directed anteriorly. The mesolophid is short in thirteen specimens and absent in twenty two specimens. The hypolophulid is transverse or directed anteriorly connecting to the longitudinal ridge in front of the hypoconid. The posterolophid reaches the base of the entoconid. The sinusid is transverse. The $\mathrm{m} 3$ has two strong roots.

Remarks: Cricetodon trallesensis n. sp. from Söke shows both plesiomorphic characters such as three rooted molars in M1 and M2 and long mesoloph in the M2 and M3 and apomorphic characters such as strongly divided anterocone, plump cusps, well developed labial anteroloph and posterior spur of paracone and the posteroloph-metalophule connection. In apomorphic characters $C$. trallesensis $\mathrm{n}$. sp. is more evolved than C. tobieni, C. kasapligili, C. versteegi and $C$. aliveriensis.

Cricetodon fikreti n. sp.

(Plate 2)

Type locality: Dededağ

Age: Early Miocene, MN4 (Ünay and Göktaş, 1999)

Holotype: M1 dext, Nr: DD, 1 
Derivatio nominis: The species is named after the geologist Fikret Göktaş who collected most of the material from Dededağ.

Material and measurements of the Cricetodon fikreti n. sp.

\begin{tabular}{|l|c|c|c|c|c|}
\hline \multirow{2}{*}{} & \multicolumn{2}{|c}{ LENGTH } & \multicolumn{2}{c|}{ WIDTH } \\
\cline { 2 - 6 } & Min-Max & Mean & $\mathrm{N}$ & Min-Max & Mean \\
\hline M1 & $2.58-2.79$ & 2.69 & 2 & $1.95-2.05$ & 2.00 \\
\hline M2 & $2.05-2.28$ & 2.20 & 6 & $1.63-1.98$ & 1.78 \\
\hline M3 & $1.55-1.80$ & 1.68 & 3 & $1.55-1.63$ & 1.58 \\
\hline m1 & $2.40-2.53$ & 2.50 & 5 & $1.55-1.60$ & 1.58 \\
\hline m2 & $2.15-2.30$ & 2.22 & 7 & $1.83-1.93$ & 1.86 \\
\hline m3 & $2.10-2.34$ & 2.22 & 2 & $1.61-1.75$ & 1.68 \\
\hline
\end{tabular}

Diagnosis: The species $C$. fikreti n. sp. is a large and rather high crowned Cricetodon. The posteroloph of the M1 and M2 continue beyond the point where the metalophule joins the posteroloph. The posterior spur of the M2 is long reaching the metacone. The labial and lingual anterolophids of the $\mathrm{m} 1$ are well developed. The metalophulid is single or double. The M1 has three roots.

Differantial diagnosis: $C$. fikreti n. sp. differs from $C$. tobieni in having plumper cusps, higher crowned cheek teeth and larger size. Additionally, the labial anteroloph is less developed in the M1, the spur of the paracone is longer, the mesoloph is shorter and the posteroloph has a more advance condition not continuing beyond the point where the metalophule meets in the M1 and M2. C. fikreti $\mathrm{n}$. sp. is much larger in size than C. kasapligili and its M1 shows distinctly divided anterocone and the posterolophs of its M1 and M2 continue beyond the point where the metalophule joins the posteroloph. C. fikreti n. sp. differs from $C$. versteegi in having much larger and higher crowned cheek teeth. Furthermore the labial anteroloph and the posterior spur of the paracone are well developed, the metalophule is directed posteriorly, the anterocone is asymmetrical and metalophulid is double in the $\mathrm{m} 1$ in C. fikreti n. sp. C. fikreti n. sp. has also much larger and rather higher crowned molars than those of $C$. aliveriensis. Moreover in C. aliveriensis the spur of the paracone is weak or absent and the mesoloph is longer in the M1 and M2. C. fikreti n. sp. differs from C. trallesensis $\mathrm{n}$. sp. from Söke in having much larger and higher crowned cheek teeth. Moreover, the labial anteroloph of the M1 is longer and usually parallel to longitudinal ridge, the posterior spur of the paracone is longer and the mesoloph is shorter in C. trallesensis n. sp.

\section{Description}

M1: The anterocone of the M1 has a mesio-labial position with the labial cusp slightly larger than the lingual one. The anterior valley is short, shallow and narrow so the anterocone is single in worn specimens. The labial and lingual anterolophs are absent. There is a transverse spur in the protosinus in three specimens. A weak protolophule I is present in one specimen out of three. The protolophule II directs posteriorly and connects to the longitudinal ridge behind the protocone. The posterior spur of the paracone and mesoloph are short. The short metalophule is strongly directed backwards being almost parallel to the longitudinal axis. The lingual sinus is transverse.

M2: The labial and lingual anterolophs are about equally well developed and connected to the paracone and the protocone respectively. The protolophule is directed posteriorly. The posterior spur of the paracone shows wide variation. It is long reaching the metacone in three out of ten M2, short in six and absent in one. The mesoloph is short or absent. The metalophule, as in the M1 is directed backwards being almost parallel to the longitudinal axis. The posteroloph reaches to the base of the metacone. The lingual sinus is directed anteriorly.

M3: The outline of the occlusal surface is elongated. The labial and lingual anterolophs are about equally well developed and connect to the paracone and the protocone respectively. The single protolophule is transverse. The posterior spur of the paracone is long or absent. The metalophule is directed posteriorly. The long posteriorly inclined mesoloph is almost parallel to the metalophule. The deep lingual sinus is directed anteriorly.

m1: The anteroconid is situated on the longitudinal axis of the occlusal surface. The labial anterolophid reaches the base of the protoconid. The lingual one is weak or absent. The metaconid and the entoconid have a posterior spur. The metalophulid is double in four out of five $\mathrm{m} 1$. The metalophulid I is directed anteriorly and connected to the anteroconid while the metalophulid II is directed posteriorly and connected to the longitudinal ridge behind the protoconid. The 
mesolophid is short. The hypolophulid is inclined anteriorly and connected to the longitudinal ridge in front of the hypoconid. The posterolophid reaches to the base of the entoconid. Most specimens have an ectomesolophid. The hypoconulid is distinct. The wide sinusid is transverse. The $\mathrm{m} 1$ has two roots.

m2: The labial anterolophid is quite strong reaching the base of the protoconid. The lingual anterolophulid is absent. The short metalophulid and hypolophulid are directed anteriorly. The former joins the middle of the anterior edge of the tooth whereas the latter joins the longitudinal ridge behind the hypoconid. The short mesolophid is directed anteriorly. The posterolophid reaches the base of the entoconid. The hypoconulid is distinct in four out of the eight specimens. The wide sinusid is transverse or directed anteriorly. The $\mathrm{m} 2$ has two roots.

m3: The labial anterolophid is rather strong reaching the base of the protoconid, the lingual one is short. The metalophulid is directed anteriorly. The mesolophid is of medium length. The transverse hypolophulid reaches the longitudinal ridge in front of the hypoconid. The sinusid is transverse.

Remarks: C. fikreti n. sp. differs from all the Eastern Mediterranean Cricetodon species in having larger and higher crowned molars. Among the early Miocene Cricetodon species, C. fikreti n. sp. resembles $C$. trallesensis n. sp. morphologically most. The smaller and lower crowned molars, longer labial anteroloph of the M1 and shorter mesoloph of the M1 and M2 of C. trallesensis n. sp., however, suggests a more primitive stage of evolution for this species. The localities, Söke and Dededağ, where these two species come from, are in superposition. So we consider these two taxa as chrono-species belonging to the same lineage.

\section{Cricetodon yapintiensis n. sp.}

\section{(Plate 3)}

Type locality: Yapınt 1

Age: Early Miocene, MN3-4 (Ünay et al., 2001)

Holotype: M1 dext., Nr: YP, 121

Derivatio nominis: The species is named after its type locality.
Material and measurements of the Cricetodon yapintiensis $\mathrm{n}$. sp.

\begin{tabular}{|l|c|c|c|c|c|}
\hline \multirow{2}{*}{} & \multicolumn{2}{|c|}{ LENGTH } & \multicolumn{3}{c|}{ WIDTH } \\
\cline { 2 - 6 } & Min-Max & Mean & $\mathrm{N}$ & Min-Max & Mean \\
\hline M1 & $2.18-2.33$ & 2.26 & 4 & $1.50-1.63$ & 1.55 \\
\hline M2 & $1.75-1.88$ & 1.83 & 4 & $1.43-1.55$ & 1.50 \\
\hline M3 & 1.63 & 1.63 & 1 & 1.35 & 1.35 \\
\hline m1 & $2.00-2.10$ & 2.05 & 3 & $1.30-1.33$ & 1.31 \\
\hline
\end{tabular}

Diagnosis: $C$. yapintiensis $\mathrm{n}$. sp. is a rather small Cricetodon. The anterocone of the M1 is divided into two cusps. The M1 has three roots. The mesoloph of the M1 and M2 is long. The posteroloph of the M1 and M2 continues beyond the point where the metalophule joins the posteroloph. The M3 is elongated. The $\mathrm{m} 1$ has a labially free weak metalophulid I.

Differential diagnosis: Cricetodon yapintiensis n. sp. is smaller than C. tobieni and C. kasapligili, but larger than $C$. versteegi and $C$. aliveriensis. $C$. yapintiensis n. sp. differ from any other early Miocene Cricetodon species in having rectangular M2. Furthermore, C. yapintiensis n. sp. differs from $C$. tobieni in having plumper cusps and less developed labial anteroloph in the M1 and elongated M3. $C$. yapintiensis n. sp. differs from C. kasapligili in having a more centrically placed and rather larger anterocone and a longer mesoloph. C. yapintiensis n. sp. differs from Cricetodon versteegi in having a more centrically situated anterocone, a shorter spur of paracone and an elongated M3. C. yapintiensis n. sp. differs from C. aliveriensis in having higher crowned cheek teeth, more centrically situated anterocone, stronger posterior spur of the paracone, shorter mesoloph in the M1 and M2 and three-rooted M1. C. yapintiensis n. sp. differs from C. trallesensis n. sp. and C. fikreti n. sp. In having smaller and rather lower crowned cheek teeth and less developed ectolophs.

\section{Description}

M1: The anterocone is situated mesio-labially and divided into two cusps in three out of the four M1. Its position is central in the remaining one specimen. The anterior valley is short, shallow and narrow. The labial anteroloph reaches the base of the paracone. The lingual anteroloph is absent. There is a transverse crest in the protosinus. One specimen shows a lingually free incipient (protolophule I?). The protolophule is 
directed posteriorly and connected to the longitidunal ridge. The posterior spur of the paracone is weak or absent. The mesoloph is of medium length. The metalophule is directed posteriorly and isolated from the posteroloph in one specimen. The posteroloph extends beyond the point where the metalophule reaches the posteroloph in three of the four M1. The lingual sinus is directed anteriorly. The M1 has three roots.

M2: M2 has a rectangular shape. The labial and lingual anterolophs are about equally well developed and connected to the paracone and the protocone respectively. The protolophule and the metalophule are directed posteriorly. The posterior spur of the paracone is either of medium length, short or absent. The mesoloph is long and directed posteriorly in one specimen but of medium length and transverse in the other three. The posteroloph reaches the base of the metacone. The lingual sinus is inclined anteriorly.

M3: The outline of the occlusal surface in the only available $\mathrm{M} 3$ is elongated. The labial and lingual anterolophs are about equally well developed and connected to the paracone and the protocone respectively. The single protolophule is directed anteriorly connecting the paracone to the protocone. The posterior spur of the paracone is long. The mesoloph is short. The lingual sinus is inclined anteriorly.

m1: The anteroconid is situated at the longitudinal axis of the occlusal surface in the only available $\mathrm{m} 1$. The labial anterolophid reaches the base of the protoconid. The lingual anterolophid is absent. The metalophulid I is weak, the metalophulid II is directed posteriorly and connected to the longitudinal ridge behind the protoconid. The metaconid and the entoconid have a posterior spur descending from their tips. The mesolophid is absent. The hypolophulid is anteriorly directed connecting to the longitudinal ridge just in front of the hypolophid. The posterolophid reaches the base of the entoconid. The transverse sinusid is with an ectomesolophid. The $\mathrm{m} 1$ has two roots.

Remarks: With its three-rooted M1, that has a weak posterior spur of the paracone, a long mesoloph and the posteroloph continuing beyond the point where the metalophule joins the posteroloph in the upper molars C. yapintiensis n. sp. is more primitive than the other early Miocene Cricetodon species except
C. versteegi. C. yapintiensis n. sp. is more evolved than $C$. versteegi in having a posteriorly directed protolophule and metalophule.

Cricetodon kasapligili de Bruijn et al., 1993

\section{(Plate 4)}

Locality: Yapınt1

Age: Early Miocene, MN 3/4 (Ünay et al., 2001)

Other localities with C. kasapligili: Keseköy, Harta Material and measurements of the Cricetodon kasapligili from Yapint1

\begin{tabular}{|l|c|c|c|c|c|}
\cline { 2 - 6 } \multicolumn{1}{c|}{} & \multicolumn{2}{c|}{ LENGTH } & \multicolumn{3}{c|}{ WIDTH } \\
\cline { 2 - 6 } \multicolumn{1}{c|}{} & Min-Max & Mean & $\mathrm{N}$ & Min-Max & Mean \\
\hline M1 & $2.50-2.63$ & 2.55 & 10 & $1.60-1.90$ & 1.76 \\
\hline M2 & $1.83-2.05$ & 1.94 & 22 & $1.70-1.93$ & 1.82 \\
\hline M3 & $1.55-1.88$ & 1.72 & 18 & $1.45-1.93$ & 1.63 \\
\hline m2 & $2.00-2.40$ & 2.19 & 14 & $1.30-1.63$ & 1.47 \\
\hline m3 & $1.88-2.10$ & 1.98 & 17 & $1.53-1.80$ & 1.66 \\
\hline
\end{tabular}

\section{Description}

M1: The anterocone is mesio-labially situated and has two cusps divided by a short, shallow and narrow anterior valley, the lingual one of these is often larger than the labial one. The labial anteroloph reaches the base of the paracone while the lingual one is absent. There is a transverse crest in the protosinus in four of the eleven M1. The anterolophule connects the protocone to the lingual part of the anterocone. The protolophule is directed posteriorly connecting to the longitudinal ridge behind the protocone. The posterior spur of the paracone is short in four specimens and absent in the remaining seven. The mesoloph is of medium length in eight specimens and short in four. The metalophule is directed posteriorly connecting to the posteroloph that extends beyond the point where the metalophule reaches the posteroloph. The lingual sinus is either transverse or directed anteriorly. The M1 has three roots.

M2: The labial and the lingual anterolophs are equally well developed and connected to the paracone and the protocone respectively. The protolophule and the metalophule are directed posteriorly. The posterior spur of the paracone is short in eighteen out of the twenty two specimens and absent in the others. The mesoloph is short and transverse in five, of medium 
length in four and long and directed posteriorly in thirteen specimens. The posteroloph extends beyond the point where the metalophule reaches the posteroloph. The lingual sinus is directed anteriorly. The M2 has four roots.

M3: The outline of the occlusal surface of the M3 is elongated. The labial and the lingual anterolophs connecting to the paracone and the protocone respectively are about the same length, but the labial one is higher than the lingual one. The single protolophule is directed anteriorly. The posterior spur of the paracone is short in eight out of eighteen and absent in the other specimens. The mesoloph is short and directed posteriorly in five, transverse and long reaching the labial cingulum in seven other specimens. A short, longitudinal, anteriorly free loph originating from the lingual part of the mesoloph is present in six specimens. The metalophule is directed anteriorly and connected to the longitudinal ridge. The posteroloph reaches the base of the metacone. The lingual sinus is directed anteriorly. The M3 has three roots.

m1: The anteroconid is small and situated at the longitudinal axis of the occlusal surface. The labial anterolophid reaches the base of the protoconid while the lingual one is weak or absent. The metalophulid is double in nine out of fourteen specimens. The metalophulid I is directed anteriorly and connected to the anteroconid, the metalophulid II is directed posteriorly and connected to the longitudinal ridge behind the protoconid. The metaconid and the entoconid have a posterior spur. The mesolophid is usually of medium length. The hypolophulid is short and connected to the longitudinal ridge in front of the hypoconid. The hypoconulid is distinct. The sinusid is transverse. The $\mathrm{m} 1$ has two strong roots.

m2: The labial anterolophid is quite strong, reaching the base of the protoconid. The lingual anterolophid reaches the base of the metaconid in three, is short in four, and absent in ten specimens. The short metalophulid is directed anteriorly. The short mesolophid is transverse or directed posteriorly. The hypolophulid is inclined anteriorly and connected to the longitudinal ridge just in front of the hypoconid. An ectomesolophid is present in two out of seventeen specimens. The posterolophid which may bear a hypoconulid is strong reaching the base of the entoconid. The sinusid is transverse or directed anteriorly. The $\mathrm{m} 2$ has two roots. m3: The labial anterolophid is strong, reaching the base of the protoconid. The lingual one is also strong, connecting to the base of the metaconid in thirteen, but is absent in the other five specimens. The short metalophulid is directed anteriorly. The mesolophid is of medium length. The hypolophulid is transverse and connected to the longitudinal ridge in front of the hypoconid. The posterolophid reaches the base of the entoconid. The sinusid is transverse. The $\mathrm{m} 3$ has two roots.

Remarks: The Yapınt Cricetodon and $C$. kasapligili from Keseköy have many common characters: size, height of crown, inflated cusps, indistinctly divided anterocone, weak posterior spur and posteroloph which continue beyond the point where the metalophule joins the posteroloph in the M1 and M2. And there are no major character differences that contradict our assignment of this material to $C$. kasapligili.

Cricetodon cf. kasapligili de Bruijn et al. 1993

\section{(Plate 5)}

\section{Locality: Harta}

Age: Early Miocene, MN3 (Göktaş and Ünay, 2000)

Other localities with $\boldsymbol{C}$. kasapligili: Keseköy, Yapıntı

Material and measurements of the Cricetodon cf. kasapligili from Harta

\begin{tabular}{|l|c|c|c|c|c|}
\hline \multirow{2}{*}{} & \multicolumn{2}{|c|}{ LENGTH } & \multicolumn{3}{c|}{ WIDTH } \\
\cline { 2 - 6 } & Min-Max & Mean & N & Min-Max & Mean \\
\hline M1 & $2.40-2.45$ & 2.43 & 2 & $1.70-1.75$ & 1.73 \\
\hline M2 & 2.10 & 2.10 & 1 & 1.80 & 1.80 \\
\hline M3 & 1.75 & 1.75 & 1 & 1.60 & 1.60 \\
\hline m1 & 2.33 & 2.33 & 1 & 1.50 & 1.50 \\
\hline m2 & $2.05-2.23$ & 2.14 & 2 & $1.75-1.88$ & 1.82 \\
\hline m3 & $2.15-2.33$ & 2.24 & 2 & $1.70-1.73$ & 1.72 \\
\hline
\end{tabular}

\section{Description}

M1: The mesio-labially or centrally situated rather narrow anterocone is divided into two cusps. The valley separating these cusps is short, shallow and narrow. The anterolophule connects the protocone to the lingual part of the anterocone. The long labial anteroloph connects to the base of the paracone in one specimen, but it absent in the other. The lingual 
anteroloph is absent. There is a transverse crest in the protosinus. The short protolophule is directed posteriorly connecting to the longitudinal ridge behind the protocone. The mesoloph is short. The metalophule is directed posteriorly. The posteroloph extends beyond the point where the metalophule reaches the posteroloph. The lingual sinus is directed anteriorly. The M1 has three roots.

M2: The labial and the lingual anterolophs are well developed and connected to the paracone and the protocone respectively. The protolophule is directed posteriorly and connected to the longitudinal ridge behind the protocone. The posterior spur of the paracone and mesoloph are short. The metalophule has a twist in the middle and is connected to the hypocone. The posteroloph reaches the base of the metacone. The sinus is directed anteriorly.

M3: The posterior part of the M3 is not much reduced. The labial and the lingual anterolophs are about equally well developed and connected to the paracone and the protocone respectively. The single, short protolophule is directed anteriorly connecting to the protocone. The posterior spur of the paracone is short. The long mesoloph is inclined posteriorly. The sinus is directed anteriorly.

m1: The posterior part of the only available $\mathrm{m} 1$ is worn. The anteroconid is situated on the longitudinal axis of the occlusal surface. The labial anterolophid reaches the base of the protoconid while the lingual one is absent. The metalophulid I is directed anteriorly and connected to the anteroconid whereas the metalophulid II is directed posteriorly connecting to the longitudinal ridge behind the protoconid. The sinusid is inclined anteriorly. The $\mathrm{m} 1$ has two roots.

m2: The labial anterolophid is rather strong reaching the base of the protoconid. The lingual anterolophid is absent. The short mesolophid is directed anteriorly. The short hypolophulid is transverse connecting to the longitudinal ridge just in front of the hypoconid. The strong posterolophid reaches the entoconid. The hypoconulid is distinct. The sinusid is transverse. The $\mathrm{m} 2$ has two roots.

m3: The labial and the lingual anterolophids are rather strong, reaching the base of the protoconid and the metaconid respectively. The short metalophulid is directed anteriorly. The mesolophid is short or absent. The strong posterolophid connects to the base of the entoconid. The sinusid is transverse.
Remarks: The Cricetodon from Harta and $C$. kasapligili from Keseköy have many characters in common: size, crown height, inflated cusps, indistinctly divided and narrow anterocone, weak posterior spur of paracone, short mesoloph and the posteroloph continuing beyond the point where the metalophule joins the posteroloph in the M1 and M2. Unfortunately, the Harta material as well as the type material are rather poor. The only available $\mathrm{m} 1$ from Harta is worn and M3 is not represented in the type material preventing further comparison. Hence, the Harta material is identified as $C$. cf. kasapligili.

\section{Cricetodon magnesiensis $\mathbf{n}$. sp.}

(Plate 6)

Type Locality: Kınık

Age: Early Miocene, MN3 (Ünay and Göktaş, 2000)

Holotype: M1 sin, Nr: KN, 101

Derivatio nominis: The species is named after Magnesia which was the ancient name of Manisa city.

Material and measurements of the Cricetodon magnesiensis n. sp.

\begin{tabular}{|l|c|c|c|c|c|}
\hline \multirow{2}{*}{} & \multicolumn{2}{|c|}{ LENGTH } & \multicolumn{3}{c|}{ WIDTH } \\
\cline { 2 - 6 } & Min-Max & Mean & $\mathrm{N}$ & Min-Max & Mean \\
\hline M1 & 2.33 & 2.33 & 1 & 1.58 & 1.58 \\
\hline M2 & $1.98-2.00$ & 1.99 & 2 & $1.73-1.80$ & 1.77 \\
\hline M3 & $1.73-1.80$ & 1.77 & 2 & $1.63-1.75$ & 1.69 \\
\hline m2 & $2.10-2.13$ & 2.12 & 2 & $1.55-1.80$ & 1.74 \\
\hline m3 & $1.90-2.15$ & 2.06 & 3 & $1.60-1.63$ & 1.59 \\
\hline
\end{tabular}

Diagnosis: Cricetodon magnesiensis $\mathrm{n}$. $\mathrm{sp}$. is a medium-sized and high crowned Cricetodon. The rather wide anterocone is divided into two unequal cusps. The posterior spur of the paracones of the M1 and M2 are long. The M3 is elongated. The M2 has three roots.

Differential Diagnosis: Cricetodon magnesiensis n. sp. differs from all the Eastern Mediterranean Cricetodon species in having rather higher crowned cheek teeth and unequal cusps of the anterocone. $C$. magnesiensis n. sp. differs from C. tobieni in having plumper cusps, longer posterior spur of the paracone, double protolophule in the M1, three-rooted M2 and elongated M3. C. magnesiensis n. sp. differs from C. kasapligili in having more labially placed and distinctly divided anterocone and strong posterior spur 
of the paracone of the M1. C. magnesiensis n. sp. have much larger and higher crowned cheek teeth than $C$. versteegi, C. aliveriensis and C. yapintiensis n. sp. $C$. magnesiensis $\mathrm{n}$. sp. differs from C. trallesensis $\mathrm{n}$. sp. in having unequally developed cusps of the anterocone and weaker posterior inclination of the mesoloph of the M1 and better developed posterior spur of the paracone in the M2. C. magnesiensis n. sp. differs from $C$. fikreti n. sp. in having labial anterolophule in the M1, less developed posterior spur of the paracone and mesoloph in the M2.

\section{Description}

M1: The anterocone is divided into two cusps in the only available M1, the labial one being larger than the lingual cusp. The anterior valley is long, deep and wide. The labial anterolophule reaches the base of the paracone while the lingual anteroloph is absent. The protolophule is directed posteriorly and connected to the longitidunal ridge. The protolophule II (?) is short. The burgee-shaped posterior spur of the paracone reaches the base of the metacone. The mesoloph is short. The weak posteroloph connects to the metacone. The wide and deep lingual sinus is transverse.

M2: The labial and lingual anterolophs connect to the paracone and the protocone respectively. The protolophule is directed posteriorly. The posterior spur of the paracone is short. The mesoloph is absent. The short metalophule is almost parallel to the longitudinal ridge. The weak posteroloph reaches the metacone. The lingual sinus is directed anteriorly.

M3: The posterior part of the M3 is reduced. The labial and lingual anterolophs are connected to the paracone and the protocone respectively. The single protolophule and the metalophule are directed anteriorly. The short mesoloph is inclined anteriorly in one specimen and posteriorly in the other. The posteroloph reaches the base of the metacone. The lingual sinus is directed posteriorly.

m2: The $\mathrm{m} 2$ is worn, so the morphological characteristics cannot be observed.

m3: The labial anterolophid is rather strong reaching the base of the protoconid while the lingual one is short. The single metalophulid is directed anteriorly. The mesolophid is absent. The hypolophulid is transverse in one specimen, directed anteriorly in the other two connecting to the longitudinal ridge in front of the hypoconid. The strong posterolophid reaches the base of the entoconid. The sinusid is transverse or directed posteriorly.

Remarks: Cricetodon magnesiensis n. sp. shows plesiomorphic features such as the elongated M3 and the posteroloph-metacone connection in upper molars as well as apomorphic characters such as strongly divided anterocone, plump cusps, well developed posterior spur of the paracone and short mesoloph in the M1. In the apomorphic characters C. magnesiensis n. sp. is more evolved than C. tobieni, C. kasapligili, C. versteegi and C. aliveriensis.

\section{Cricetodon versteegi de Bruijn et al. 1993}

\section{(Plate 7)}

\section{Locality: Kınık}

Age: Early Miocene, MN3 (Ünay and Göktaş, 2000)

Other localities with C. versteegi: Kılçak 0", Kılçak 3a

Material and measurements of the Cricetodon versteegi from Kınık

\begin{tabular}{|l|c|c|c|c|c|}
\hline \multirow{2}{*}{} & \multicolumn{2}{|c|}{ LENGTH } & \multicolumn{3}{c|}{ WIDTH } \\
\cline { 2 - 6 } & Min-Max & Mean & $\mathrm{N}$ & Min-Max & Mean \\
\hline M1 & $1.98-2.23$ & 2.12 & 3 & $1.48-1.58$ & 1.53 \\
\hline M2 & $1.53-1.68$ & 1.62 & 13 & $1.40-1.65$ & 1.53 \\
\hline M3 & $1.20-1.40$ & 1.31 & 11 & $1.25-1.43$ & 1.35 \\
\hline $\mathrm{m} 1$ & $1.83-2.03$ & 1.92 & 9 & $1.20-1.35$ & 1.27 \\
\hline $\mathrm{m} 2$ & $1.65-1.85$ & 1.75 & 8 & $1.35-1.48$ & 1.43 \\
\hline $\mathrm{m} 3$ & $1.55-1.75$ & 1.67 & 9 & $1.30-1.43$ & 1.35 \\
\hline
\end{tabular}

\section{Description}

M1: The rather wide anterocone of the M1 has a labial position and is divided into two equal cusps. The valley between these cusps is long, deep and wide. The labial anteroloph reaches the base of the paracone while the lingual one is absent. A weak protolophule I is present in all the three specimens. The protolophule is directed posteriorly and connected to the longitudinal ridge behind the protocone. The posterior spur of the paracone is long reaching the metacone. The mesoloph is short. The metalophule is directed posteriorly. The posteroloph extends beyond the point where the metalophule reaches the posteroloph. The wide and deep lingual sinus is transverse or directed posteriorly. The M1 has three roots. 
M2: The labial and lingual anterolophs are long connecting to the paracone and the protocone respectively. The protolophule I is present, but protolophule II is absent in four out of twelve specimens, the protolophule II is present and while the protolophule I is absent in thee specimens and the both protolophules are absent in the other specimens. The posterior spur of the paracone is short. The mesoloph is short in two specimens, absent in the others. The posteroloph reaches to the base of the metacone. The lingual sinus is transverse or directed posteriorly. The M2 has three roots.

M3: The outline of the occlusal surface of the M3 is rounded. Both the labial and the lingual anterolophs are about equally long reaching the base of the paracone and the protocone respectively. The single protolophule is directed anteriorly. The mesoloph shows considerable variation in length: It is being long in one out of nine M1, short in four and absent in the other four. The metalophule is directed anteriorly. The posteroloph reaches the base of the metacone. The lingual sinus is directed anteriorly.

m1: The anteroconid is situated labially. The labial anterolophid reaches the base of the protoconid. The lingual one is absent. The metalophulid I is directed anteriorly and connected to the anteroconid while the metalophulid II is directed posteriorly and connected to the protoconid. The mesolophid is absent. The wide hypolophulid is anteriorly directed, connecting to the longitudinal ridge in front of the hypoconid. The posterolophid reaches the base of the entoconid. The sinusid is inclined anteriorly. The $\mathrm{m} 1$ has two roots.

m2: The labial anterolophid is rather strong reaching the base of the protoconid while the lingual one is weak. The short metalophulid is directed anteriorly. The mesolophid is short. The hypolophulid is directed anteriorly and connected to the longitudinal ridge in front of the hypoconid. The posterolophid which may bear a hypoconulid is strong reaching the base of the entoconid. The sinusid is directed anteriorly. The $\mathrm{m} 2$ has two roots.

m3: The strong labial anterolophid is connected to the base of the protoconid while the lingual one is absent. The anteriorly directed metalophulid is short. Mesolophid is also short and inclined posteriorly. The hypolophulid is transverse or directed anteriorly connecting to the longitudinal ridge in front of the hypoconid. The strong posterolophid reaches the base of the entoconid. The sinusid is transverse or directed anteriorly. The $\mathrm{m} 3$ has two roots.

Remarks: Although, the Cricetodon material from Kinık is somewhat larger than C. versteegi from the type locality Kılçak 3a, it shares many characters with the type association: three-rooted M1 and M2, wide, centrally placed, clearly bi-cuspid anterocone, well developed labial anterolophule, spur of the paracone and protolophule I in the M1, anteriorly directed metalophule in the M2, rounded M3 with single protolophule and assymetric anteroconid complex and double metalophulid in the $\mathrm{m} 1$. Therefore the second Cricetodon assemblages from Kınık have been included in the species Cricetodon versteegi.

\section{Deperetomys Mein and Freudenthal, 1971}

\section{Deperetomys cf. intermedius}

(Plate 8)

Locality: Kınık

Age: Early Miocene, MN3 (Ünay and Göktaş, 2000)

Other localities with D. intermedius: Harami 1, Harami 3

Material and measurements of the Deperetomys ef. intermedius from the Kınık

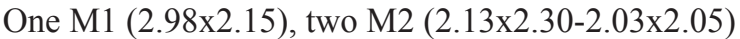

\section{Description}

M1: The rather wide anterocone of the M1 has a mesio-labial position and two completely separated cusps. The posterior spur of the labial cusp of the anterocone is burgee-shaped and tends to close the antero-labial sinus. The posterior spur of the lingual cusp of the anterocone reaches the base of the protocone. The weak protolophule I and the protolophule II connect the paracone to the protocone anteriorly and posteriorly. The burgee-shaped posterior spur of the paracone reaches the labial edge. The mesoloph is long. The burgee-shaped anterior spur of the metacone reaches the mesoloph. The strong posteriorly directed metalophule is connected to the posteroloph. There is low endomesoloph in the transverse lingual sinus. The M1 has four roots.

M2: The labial and the lingual anterolophs are strong; lingual one being lower than the labial one. 
They connect to the paracone and the protocone respectively. The protolophule is connected to the postero-labial part of the protocone. The long and burgee-shaped posterior spur of the paracone reaches the labial edge. The mesoloph is long and connected to the anterior spur of the metacone. The metalophule is directed posteriorly meeting the posteroloph. The endomesoloph is indistinct. The lingual sinus is transverse. The M2 has four roots.

Remarks: The Kını Deperetomys and D. intermedius from Harami 1 have many characters in common: size, crown height, completely separated anterocone, well developed posterior spur of the labial cusp and weak protolophule I in the M1, long mesoloph in the M1 and M2. Unfortunately, the Kinık material is poor, only one M1 and two M2 are available. Hence the Kınık material is identified as $D$. cf. intermedius. The stratigraphical range of the genus Deperetomys is from MN 1 to $7 / 8$ with a long gap between MN2-MN7/8. The Kınık finding fills the MN3 part of this gap.

\section{Paleogeography and Paleoecology}

According to de Bruijn and Ünay (1996) Cricetodontini members appeared as immigrants into Asia Minor around the Oligo-Miocene boundary, because there are no potential ancestors known from the area from older levels than MN1. Biogeographical distribution of Cricetodontini follows a symmetrical model, in which the first occurrence of the tribe is in a small area during the early Miocene (Alvarez-Sierra et al., 2013). The diversity of the tribe starting in MN4 was accompanied by migration westward, first into southeastern Europe and later (MN5) into southwestern Europe. During the MN 6, the genus reached its maximum geographic range. Since the late middle Miocene, the distribution area of the representatives of the tribe starts to show fragmentation and contraction that precede the extinction at the end of the Pliocene (Alvarez-Sierra et al., 2013). The new discoveries of Chinese Cricetodon species suggests that the diversification of the Cricetodon was accompanied not only by migration westward, but also migration eastward into Central Asia and China (Bi, 2005).

The diversity and geographical expansion of the tribe (MN4) coincides with the drop in diversity of the insectivore faunas in Anatolia. This suggestion has been interpreted as indicating that the climate become drier and the Cricetodontini preferred drier biotopes (de Bruijn and Ünay, 1996).
The genus Deperetomys occurs in Anatolia and in central and south western Europe. The oldest record of genus is from Anatolia where it appears in MN12-3. The first appearance of Deperetomys in Central and South Western Europe however is in MN 6-8. This indicates a westward migration of the genus. The stability of the dental structure of Deperetomys over a long period-as in having forwards directed lophs in the lower molars, backwards directed lophs in upper molars and four roots in M1 and M2- suggests that the species of Deperetomys occupied a very special ecological niche. The combination of gracile cheek teeth and very strong roots make it unlikely herbivores (de Bruijn et al., 1993).

The distribution of the various species of Cricetodontini in time of the different localities is shown in figure 3. (modified from de Bruijn et al., 1993).

\section{Phylogeny of the Genus Cricetodon}

The phylogenetic analysis of the tribe Cricetodontini and the genus Cricetodon have been largely discussed in some previous studies (Bi, 2005; Sen and Erbajeva, 2011; Maridet and Sen, 2012; Lopez Guerro, 2014; Prieto et al., 2014). Bi's (2005) phylogenetic analysis forms a basis for our attempt of phylogenetic analysis of Cricetodon in this study. Euricetodon collatus considered as a primitive cricetid (Bi, 2005) which has been selected as out-group. Out of the known twenty eight Cricetodon species twenty five were selected for this analysis (see Table 1). Since the species Cricetodon jumanensis (Rummel, 2001) is represented by two teeth and Cricetodon volkeri $(\mathrm{Wu}, 2009)$ is represented with three teeth only, these species have not been included. "Cricetodon" fandli (Prieto et al., 2010) has been excluded because its allocation to Cricetodon is uncertain. The species $C$. bolligeri, C. klariankae, C. soriae, C. engesseri, $C$. nievei and $C$. wanhei which were not included in Bi's (2005) analysis were added in this study.

The software of phylogenetic reconstruction used was PAST 2.08 (Hammer et al., 2001). A total of thirty phylogenetically informative characters of the upper and lower molars and their characteristic states have been adopted from Bi (2005). Eighteen characters are binary whereas twenty are multistate. Characters are listed in Table 1. Missing data or not represented character states in some species are coded with a question mark (?).

Thirty phylogenetically informative characters and their character states are shown in Appendix 1. 
Bull. Min. Res. Exp. (2016) 152:85-119

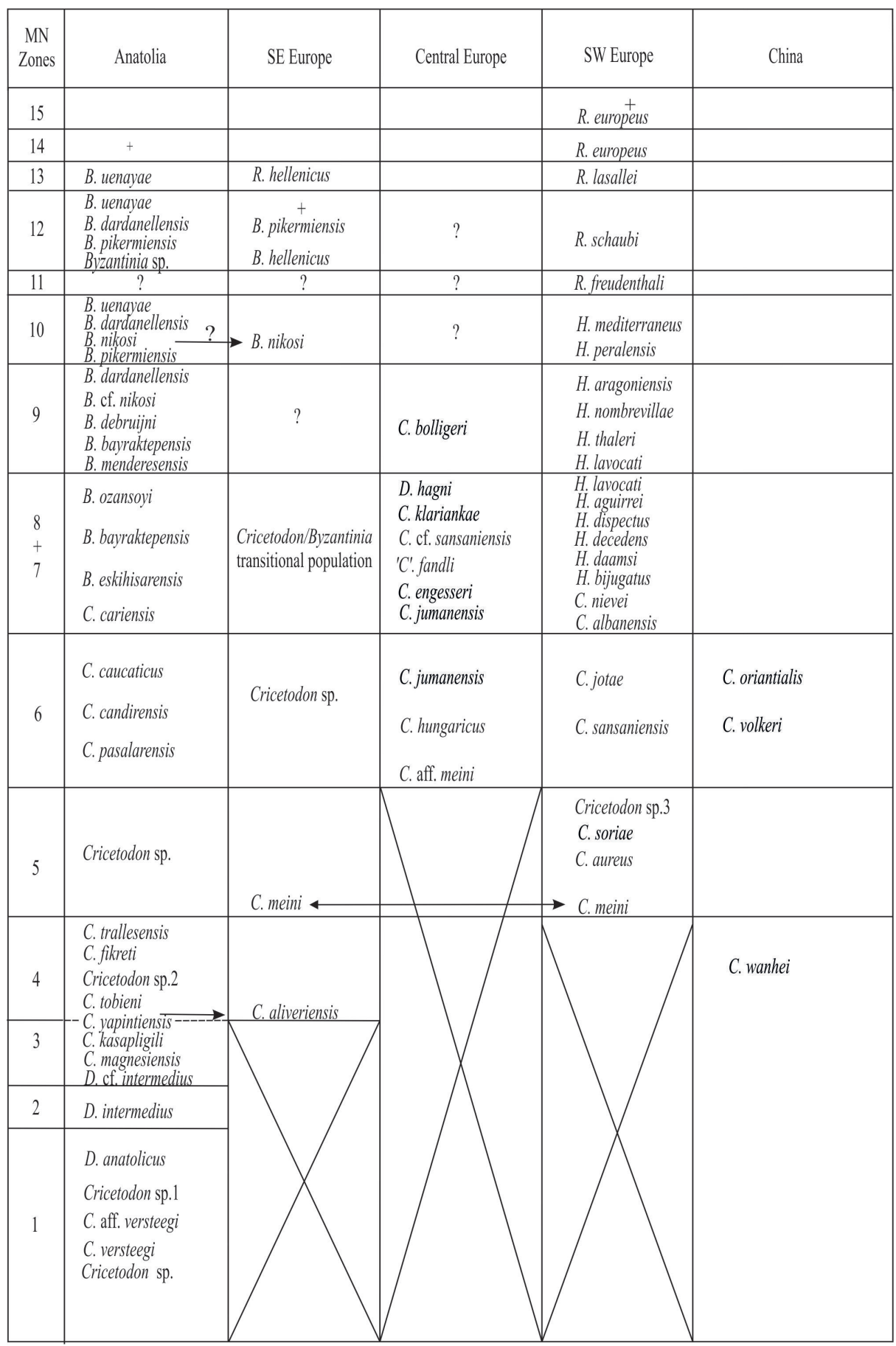

Figure 3- The distribution of the various species of Cricetodontini in time of the different localities (modified from de Bruijn et al., 1993)

\subsection{Results}

According to the outcome shown in figure 4 Cricetodon versteegi is the most primitive lineage and the early Miocene species of the Eastern Mediterranean area are more primitive and more closely related to each other than to the Cricetodon species from in the other regions.
Within the early Miocene Cricetodon species from Anatolia C. yapintiensis n. sp., C. trallesensis n. sp. and $C$. magnesiensis n. sp. constitute a clade and $C$. fikreti $\mathrm{n}$. sp. appears as a sister group of this clade.

C. orientalis is located between the Anatolian Cricetodon species and European species. C. meini and $C$. aureus are more primitive species and they 


\section{Cricetodontini From the Early Miocene of Anatolia}

Table 1- Matrix of character coding used in the analysts of relationships of species of Cricetodon. Question mark indicate missing data, $\mathrm{A}$ indicate polymorphisms; $\mathrm{A}=0 / 1$.

\begin{tabular}{|c|c|c|c|c|c|c|c|c|c|c|c|c|c|c|c|c|c|c|c|c|c|c|c|c|c|c|c|c|c|c|}
\hline Species/Characters & 1 & 2 & 3 & 4 & 5 & 6 & 7 & 8 & 9 & 10 & 11 & 12 & 13 & 14 & 15 & 16 & 17 & 18 & 19 & 20 & 21 & 22 & 23 & 24 & 25 & 26 & 27 & 28 & 29 & 30 \\
\hline E. collatus & 0 & 0 & 0 & 0 & 0 & $?$ & 0 & 0 & 0 & 0 & 0 & 0 & 0 & 0 & $?$ & 0 & 0 & 0 & 0 & 0 & 0 & 0 & 0 & 0 & 0 & 0 & 0 & 0 & 0 & 0 \\
\hline C. versteegi & 2 & 1 & 0 & A & 1 & $?$ & A & 1 & 0 & 0 & 0 & 1 & 0 & 0 & $?$ & 1 & 0 & 1 & 0 & 1 & 1 & 0 & 2 & 0 & 0 & 1 & 0 & 0 & 0 & 0 \\
\hline C. kasapligili & A & 1 & 0 & A & 0 & $?$ & 1 & 1 & 0 & 1 & 1 & 1 & 0 & 0 & $?$ & 1 & 1 & $?$ & $?$ & $?$ & 0 & 0 & 2 & 0 & $?$ & $?$ & $?$ & 0 & 0 & 1 \\
\hline C. tobieni & 2 & 0 & 0 & A & 1 & $?$ & 1 & 1 & 0 & 1 & 1 & 1 & 0 & 1 & $?$ & 1 & 1 & 1 & 0 & 1 & A & 0 & 1 & 0 & 0 & 1 & 0 & 0 & 0 & 1 \\
\hline C. yapintiensis & 2 & 1 & 2 & 1 & 0 & $?$ & 1 & 1 & 0 & 1 & 1 & 1 & 1 & 1 & $?$ & 1 & $?$ & 0 & 1 & $?$ & 0 & 0 & 2 & 0 & $?$ & $?$ & $?$ & $?$ & $?$ & $?$ \\
\hline C. aliveriensis & 2 & 0 & 0 & 0 & 0 & $?$ & 1 & 2 & 1 & 1 & 1 & 1 & 0 & 1 & $?$ & 2 & 1 & 0 & 0 & 1 & 1 & 0 & 1 & 0 & 0 & 1 & 0 & 0 & 0 & 1 \\
\hline C. trallesensis & 2 & 1 & 2 & A & 2 & A & 1 & 2 & 0 & 1 & 1 & 2 & A & 1 & $?$ & 2 & 0 & A & 1 & 0 & A & 0 & 2 & 0 & 0 & 1 & 0 & 0 & 1 & 1 \\
\hline C. fikreti & 2 & 1 & 0 & A & 1 & $?$ & 1 & 2 & $?$ & 1 & 1 & 1 & 1 & 1 & $?$ & 2 & $?$ & 0 & 0 & 1 & 1 & 0 & 2 & 0 & 1 & 1 & 0 & 0 & 1 & 1 \\
\hline C. magnesiensis & 2 & 1 & 2 & 1 & 2 & 1 & 1 & 1 & $?$ & 1 & 1 & 2 & 1 & 1 & $?$ & 2 & $?$ & 0 & 1 & 0 & $?$ & $?$ & ? & $?$ & $?$ & $?$ & $?$ & 0 & 1 & 2 \\
\hline C. orientalis & 1 & 1 & 0 & 1 & 1 & $?$ & 2 & 2 & 1 & 1 & 1 & 1 & 0 & 1 & $?$ & 2 & 1 & 1 & 0 & 1 & 1 & 0 & 2 & 0 & 0 & 1 & 0 & 0 & 0 & 0 \\
\hline C. meini & A & 1 & 0 & 1 & 0 & $?$ & 2 & 2 & 1 & 1 & 1 & 2 & 0 & 0 & $?$ & 2 & 1 & 1 & 0 & 1 & A & 0 & 2 & 0 & 0 & 1 & 0 & 1 & 0 & 1 \\
\hline C. aureus & A & 1 & 0 & 1 & 0 & $?$ & 2 & 2 & 1 & 1 & 1 & 2 & 0 & 0 & $?$ & 2 & 1 & 1 & 0 & 1 & 0 & 0 & 2 & 0 & 0 & 1 & 0 & 1 & 0 & 1 \\
\hline C. sansaniensis & 2 & 1 & 0 & 1 & 0 & $?$ & 2 & 2 & 1 & 1 & 1 & 2 & 0 & 1 & $?$ & 2 & 1 & 1 & 0 & 1 & A & 0 & 2 & 0 & 0 & 1 & 0 & 1 & 0 & 1 \\
\hline C. jotae & 2 & 1 & 0 & 1 & 0 & $?$ & 2 & 2 & 1 & 1 & 1 & 2 & 0 & 1 & $?$ & 2 & 1 & 1 & 0 & 1 & 1 & 1 & 2 & 0 & 0 & 1 & 0 & 1 & 0 & 1 \\
\hline C. albanensis & 2 & 1 & 1 & 1 & 0 & $?$ & 1 & 2 & 1 & 1 & 1 & 2 & 0 & 1 & $?$ & 2 & 1 & 1 & 1 & 1 & 1 & 1 & 2 & 0 & 0 & 1 & 0 & 1 & 1 & 1 \\
\hline C. pasalarensis & 2 & 1 & 1 & 1 & 2 & 0 & 2 & 2 & 1 & 1 & 1 & 2 & 0 & 2 & 0 & 2 & 1 & 1 & 0 & 1 & A & 0 & 2 & 1 & 1 & 1 & 1 & 0 & 0 & 1 \\
\hline C. caucaticus & 2 & 1 & 1 & 1 & 2 & 0 & 2 & 2 & 1 & 1 & 1 & 1 & 1 & 2 & 0 & 2 & 1 & 1 & 0 & 0 & 0 & 0 & 2 & 1 & 1 & 2 & 2 & 0 & 0 & 1 \\
\hline C. hungaricus & 2 & 1 & 1 & 1 & 2 & 1 & 1 & 2 & 1 & 1 & 1 & 1 & 1 & 2 & 1 & 2 & 1 & 0 & 0 & 0 & 1 & 0 & 1 & 1 & 1 & 1 & 1 & 0 & 0 & 1 \\
\hline C. candirensis & 2 & 1 & 2 & 1 & 2 & 1 & 1 & 2 & 1 & 1 & 1 & 1 & 1 & 2 & 1 & 2 & 1 & 0 & 0 & 0 & 0 & 0 & 2 & 1 & 1 & 1 & 1 & 0 & 1 & 1 \\
\hline C. cariensis & 2 & 0 & 1 & 1 & 2 & 1 & 1 & 2 & 1 & 1 & 1 & 1 & 1 & 2 & 1 & 2 & 0 & 0 & 0 & 0 & 0 & 0 & 2 & 1 & 1 & 1 & 1 & 0 & 1 & 1 \\
\hline C. klariankae & 2 & 1 & 1 & 0 & 2 & 0 & 2 & 2 & 1 & 1 & 1 & 2 & 1 & 2 & 0 & 2 & 1 & 0 & 1 & 0 & 0 & 0 & 2 & 1 & 1 & 2 & 1 & 1 & 1 & 2 \\
\hline C. bolligeri & 1 & 1 & 1 & 0 & 1 & $?$ & 2 & 2 & 1 & 1 & 1 & 2 & 1 & 1 & $?$ & 2 & 1 & 1 & 2 & 1 & 0 & 0 & 2 & 1 & 1 & 2 & 1 & 1 & 1 & 2 \\
\hline C. soriae & 2 & 1 & 0 & 1 & 1 & $?$ & 2 & 1 & 1 & 1 & 1 & 2 & 0 & 1 & $?$ & 2 & 1 & 0 & A & 0 & 1 & 1 & 2 & 0 & 1 & 1 & 0 & 0 & 1 & 1 \\
\hline C. nievei & 2 & 1 & 1 & 0 & 1 & $?$ & 2 & 1 & 1 & 2 & 1 & 2 & A & 1 & $?$ & 2 & $?$ & 1 & 2 & 1 & 1 & 1 & 2 & 0 & 1 & 2 & 0 & 0 & 1 & 2 \\
\hline C. engesseri & 1 & 1 & 2 & 0 & 1 & $?$ & 2 & 1 & $?$ & 1 & 1 & 2 & 0 & 1 & 0 & 2 & $?$ & 0 & 0 & 1 & 1 & 1 & 1 & 0 & 1 & 1 & 0 & $?$ & $?$ & 0 \\
\hline C. wanhei & A & 1 & 1 & 0 & 1 & $?$ & 2 & 1 & 1 & 0 & 1 & 2 & 0 & 1 & ? & 1 & 1 & 0 & 2 & 1 & 1 & 1 & 2 & 0 & 1 & 2 & 0 & 0 & 0 & 1 \\
\hline
\end{tabular}

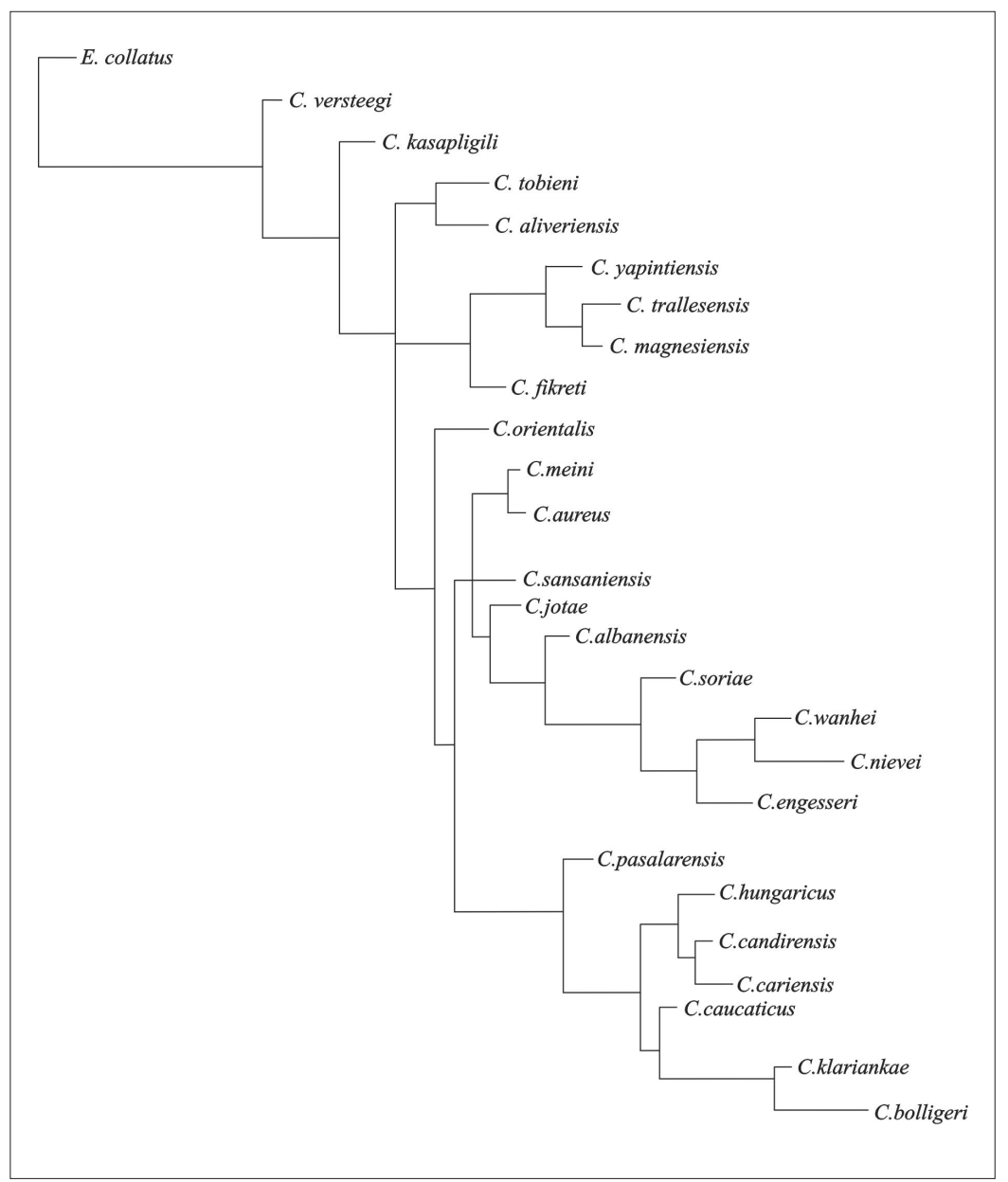

Figure 4- Cladogram illustrating the relationships among the species of the Cricetodon. Tree statistics: Length $=120$, Consistency Index $=0,359$, Retention Index $=0,72$ 
are known as being earlier cricetodons of Europe. As is seen in this analysis, C. sansaniensis is usually considered as derived from C. aureus and compared to the Anatolian species, these species are an independend lineage.

The other clade is mainly included advanced Anatolian and European species. C. pasalarensis is the basal position of this group. This analysis is shown that $C$. hungaricus, C. klariankae and C. bolligeri migrated from Anatolia.

This analysis also supports that the Cricetodon species do not form a monophyletic group.

\section{Acknowledgments}

We thank to the Fikret Göktaş, Gerçek Saraç and Eşref Atabey for supporting the fieldwork during the MTA geology projects which are carried out between the years of 1992-2001 are studied. We are grateful to the Hans de Bruijn (Utrecht University, The Netherlands) for useful comments and suggestions. We thank to Okan Zimitoğlu and Tolga Görmüş for taking SEM photographs.

\section{References}

Alvarez-Sierra, M. A., I. Garcia-Paredes, V., HernandezBallarin, L.W., Van den Hoek Ostende, K., Hordijk, P. Lopez-Guerrero, A. J., Van der Meulen, A., Oliver, and Pelaez-Campomanes, P. 2013. Models of historical biogeography and continental biochronology. Spanish Journal of Palaeontology, 28, 129-138.

Argyropulo, A. I. 1938. On the fauna of Tertiary Cricetidae of the USSR. Comptes Rendus (Doklady) de l'Acad'emie des Sciences de l'URSS, 20, 223-226.

Bi, S.D. 2005. Evolution, systematics and functional anatomy of a new species of Cricetodontini (Cricetidae, Rodentia, Mammalia) from the northern Junggar Basin, northwestern China. Ph. D. Thesis. Howard University, 183 p. Washington DC (unpublished).

de Bruijn, H., Fahlbusch, V., Saraç, G., Ünay E. 1993. Early Miocene rodent faunas from the Eastern Mediterranean area. Part III. The genera
Deperetomys and Cricetodon, with a discussion of the evolutionary history of the Cricetodontini. Proceedings van de Koninklijke Nederlandse Akademie van Wetenschappen Series, 96, 2, 151216.

de Bruijn, H., Ünay, E. 1996. On the evolutionary History of the Cricetodontini from Europe and Asia Minor and It's Bearing on the Reconstruction of Migrations and the Continental Biotope During the Neogene. In Bernor, R.L., Fahlbusch, V. and Mittmann, H.W. (Ed.). The Evolution of Western Eurasian Later Neogene Faunas, 227-234. New York: Columbia University Press.

Fernández, M. H., Cárdaba J. A., Cuevas-González, J., Fesharaki O., Salesa M. J., Corrales, B., Domingo, L., Elez J., López Guerrero P., Sala-Burgos N., Morales J., López Martínez N. 2006. Los yacimientos de vertebra dos del Mioceno medio de Somosaguas (Pozuelo de Alarcón, Madrid): implicaciones paleoambientales y paleoclimáticas. Estudios Geológicos, 62, 1, 263-294.

Freudenthal, M. 1963. Entwicklungsstufen dermioz “anen Cricetodontinae (Mam. Rod.), Mittelspaniens und ihre stratigraphische Bedeutung. Beaufortia, 10, $51-157$.

Göktaş, F., Ünay, E. 2000. The stratigraphy of the NW parts of the Akhisar (Manisa) Neogene basin. International Earth Science Congress on Aegean Region, Abstracts, p. 72.

Hammer, Ø., Harper, D.A.T., Ryan P.D. 2001. Paleontological statistics software package for education and data analysis. Paleontologica Electronica, 41, p, 9.

Hír, J. 2007. Cricetodon klariankae n. sp. (Cricetodontini, Rodentia) from Felsötárkány-Felnémet (Northern Hungary). Fragmenta Paleontologica Hungarica, 24-25, 16-24.

Jarvis, A., Reuter, H.I., Nelson, A., Guevara, E. 2008. Holefilled SRTM for the Globe, Version 4. CGIAR-CSI SRTM 90m Database, http://srtm.csi.cgiar.org.

Klein Hofmeijer, G., de Bruijn, H. 1988. The mammals from the lower Miocene of Aliveri (Island of Evia, Greece) part 8: the Cricetidae. Proceedings of the Koninklijke Nederlandse Akademie van Wetenshappen Series B, 91, 185-204. 
Kordos, L. 1986. Upper Miocene hamsters (Cricetidae, Mammalia) of Hasznos and Szentendre. Magyar Allami Földtani Intézet Jelentése Az, 1984, 523553.

Lartet, E. 1851. Notice sur la colline de Sansan, suivie d'unerécapitulation des diverses espéces d'animaux vertébrés fossiles trouvés soit á Sansan, soint dans d'autres gisements du terrain tertiaire miocéne dans le Bassin Sous-Pyrénéen. J. A. Portes, Auch, 41 pp.

López-Guerrero, P. 2014. Cricetodontini (Rodentia, Mammalia) del Mioceno medio y superior del área de Daroca (Aragón, España): sistemática y filogenia. Ph. D. Thesis. Unıversidad Complutense De Madrid, 388 p. Madrid (unpublished).

López-Guerrero, P., García-Paredes, I., Álvarez-Sierra, M.A. 2013. Revision of Cricetodon soriae (Rodentia Mammalia), new data from the middle Aragonian (Middle Miocene) of the Calatayud-Daroca Basin (Zaragoza, Spain). Journal of Vertebrate Paleontology, 33, 169-184.

López-Guerrero, P., Álvarez-Sierra, M.A., GarcíaParedes, I., Peláez-Campomanes, P. 2014. New Cricetodontini from the middle Miocene of Europe: an example of mosaic evolution. Bulletin of Geosciences, 89. Czech Geological Survey, Prague. ISSN 1214-1119.

Maridet, O., Sen, S. 2012. Les Cricetidae du gisement de Sansan. Peigné, S., Sen, S. (Ed.). Mammifères de Sansan. Mémoires du Muséum d'Histoire Naturelle de Paris, 203, 29-65.

Mein P, Freudenthal M. 1971a. Les Cricetidae (Mammalia, Rodentia) du Néogène Moyen de vieux-Collonges Partie 1: Le genre Cricetodon Lartet, 1851. Scripta Geologica, 5, 1-49.

Mein, P., Freudenthal, M. 1971b. Les Cricetidae (Mammalia, Rodentia) du Neogene Moyen de Vieux-Collonges. Partie 1: Le genre Cricetodon Lartet, 1851. Scripta Geologica, 5, 1-51.

Prieto J., Böhme M., Gross, M. 2010. The cricetid rodents from Gratkorn (Austria, Styria): a benchmark locality for the continental Sarmatian sensu stricto (late Middle Miocene) in the Central Paratethys. Geologica Carpathica,61, 5, 419-436.
Prieto, J., Angelone, C., Casanovas-Vilar, I., Gross, M., Hír, J., Hoek Ostende L.W. van den, Maul, L., Vasylian, D. 2014. The small mammals from Gratkorn: an overview. Palaeobiodiversity and Palaeoenvironments, 94, 1, 135-162.

Qiu, Z. D. 2010. Cricetids rodents from the early Miocene Xiacaowan formation, Sihong, Jiangsu. Vertebrata PalAsiatica, 48, 27-47.

Reig, O. A. 1977. A proposed unified nomenclature for the enameled components of the molar teeth of the Cricetidae (Rodentia). Journal of Zoology (London), 181, 227-241.

Rummel, M. 1995. Cricetodon bolligeri n. sp. ein neuer Cricetide aus dem Obermiozän von Petersbuch bei Eichstätt. Mitteilungen der Bayerischen Staatssammlung für Paläontologie und Historische Geologie, 35, 109-123.

Rummel, M. 2001. Ein neuer Cricetodon aus dem Miozän von Petersbuch bei Eichstätt. Stuttgarter Beiträge zur Naturkunde B, 311, 1-6.

Rummel, M., D. Kälin. 2003. Die Gattung Cricetodon (Mammalia, Rodentia) aus den Mittelmiozän der Schweizer Molasse. Zitteliana, 43, 123-141.

Simpson, G.G. 1945. The principles of classification and a classification of mammals. Bulletin of the American Meseum of Natural History, 85, 1-350.

Şen, S., Ünay, E. 1979. Sur quelques Cricetodontini (Rod.) $\mathrm{du}$ Miocéne moyen d'Anatolie. Proceedings of the Koninklijke Nederlandse Akademie van Wetenshappen, 82, 293-301.

Şen, S., Erbajeva, M. A. 2011. A new species of Gobicricetodon Qiu, 1996 (Mammalia, Rodentia, Cricetidae) from the Middle Miocene of Aya Cave, Lake Baikal. Vertebrata PalAsiatica, 49, 257-274.

Tobien, H. 1978. New species of Cricetodontini (Rod. Mam.) from the Miocene of Turkey. Mainzer Geowissenschaftliche Mitteilungen Geologisches Landesamt Rheinland-Pfalz, 6, 209-219.

Ünay, E., Göktaş, F. 1999. Söke çevresi (Aydın) Geç Erken Miyosen ve Kuvaterner yaşlı küçük memelileri: ön sonuçlar. Türkiye Jeoloji Bülteni, 42, 2, 99-115.

Ünay, E., Göktaş, F. 2000. Kınık (Gördes) çevresindeki Erken Miyosen yaşlı linyitli çökellerin küçük memeli biyokronolojisi: ön sonuçlar. Türkiye Jeoloji Bülteni, 43, 1, 1-5. 
Ünay, E., Atabey, E., Saraç, G. 2001. Small mammals and foraminifera from the Anatolian (Central Taurus) Early Miocene. Annals of Carnegie Museum, 70, 4, 247-256.

Wu, W., Meng, J., Ye, J. Ni, X. J., Bi, S.D., Wei, Y. P. 2009. The Miocene mammals from Dingshanyanchi formation of North Junggar Basin, Xinjiang. Vertebrata Palasiatica, 47, 3, 208-233.

\section{Appendix 1:}

1. Bifurcation of anterocone on M1:

(0) single, undivided cusp; (1) slight incision in the wall of the anterocone; separation of antero-lingual and antero-labial conules into distinct cusps at the top; (2) deep incision in the wall of the anterocone; separation of antero-lingual and antero-labial conules into distinct cusps at the base

\section{Inflation of cusps: \\ (0) slender; (1) plump}

\section{Labial anteroloph of M1:}

(0) absent, or weakly developed; (1) a short spur; (2) complete

\section{Protolophule I of M1:}

(0) absent; (1) a labial spur on the anterolophule pointing to the paracone

5. Posterior spur of the paracone of M1:

(0) absent; (1) a posterior spur on the paracone; (2) a complete crest between paracone and metacone

6. Shape of posterior spur of the paracone:

(0) straight; (1) concave

\section{Mesoloph on M1:}

(0) long, extending from median mure to labial cingulum; (1) of medium length, about half the distance between median mure and labial cingulum; (2) absent, or minimally suggested in unworn molars as an enamel deflection of the median mure

\section{Posteroloph of M1:}

(0) a transverse elongate ridge, surrounding a basined protosinus posteriorly with a metalophule; (1) continues beyond the point where it meets the metalophule; (2) not continuing beyond the point where it meets the metalophule

\section{M1 roots:}

(0) three roots; (1) four roots

10. Protolophule of M2:

(0) connected to the anterior branch of the protocone, or to its anterior corner; (1) connected to the posterior corner of the protocone or to the entoloph

11. Metalophule of M2:

(0) connected to the anterior tip of the hypocone, or to the entoloph; (1) connected to the posterior tip or posterior branch of the hypocone

12. Mesoloph of M2:

(0) long, extending from median mure to labial cingulum; (1) of medium length, about half the distance between median mure and labial cingulum; (2) absent, or minimally suggested in unworn molars as an enamel deflection of the median mure

\section{Sinus of M2:}

(0) relatively wide and almost transverse; (1) relatively narrow and directed forwards

14. Posterior spur of the paracone of M2:

(0) absent; (1) a posterior spur on the paracone; (2) a complete crest between paracone and metacone

15. Shape of posterior spur of the paracone:

(0) straight; (1) concave

16. Posteroloph of M2:

(0) a transverse elongate ridge, surrounding a basined protosinus posteriorly with a metalophule; (1) continuing beyond the point where it meets the metalophule; (2) not continuing beyond the point where it meets the metalophule

\section{7. $\mathrm{M} 2$ roots:}

(0) three roots; (1) four roots

18. Shape of reduced M3:

(0) elongate; (1) rounded

19. Mesoloph of M3:

(0) long, extending from median mure to labial cingulum; (1) of medium length, about half the distance between median mure and labial cingulum; (2) absent, or minimally suggested in unworn molars as an enamel deflection of the median mure 
20. Metacone of M3:

(0) distinct; (1) ridge-like

21. Metalophulid I of $\mathrm{m} 1$ :

(0) absent; (1) present

22. Metalophulid II of $\mathrm{m} 1$ :

(0) present; (1) absent

23. Mesolophid of $\mathrm{m} 1$ :

(0) long, reaching the border of the molar; (1) of medium length, about half the distance between the longitudinal ridge and lingual border; (2) short, or absent

24. Sinusid of $\mathrm{m} 1$ :

(0) relatively wide and almost transverse; (1) relatively narrow and directed forwards

25. Lingual anterolophid of $\mathrm{m} 2$ :

(0) developed; (1) undeveloped
26. Mesolophid of $\mathrm{m} 2$ :

(0) long, reaching the border of the molar; (1) of medium length, about half the distance between the longitudinal ridge and lingual border ; (2) short, or absent

27. Sinusid of $\mathrm{m} 2$ :

(0) relatively wide and almost transverse; (1) relatively narrow and directed forwards

28. Shape of reduced $\mathrm{m} 3$ :

(0) elongate; (1) round

29. Protosinusid of $\mathrm{m} 3$ :

(0) circular; (1) retracted and directed forwards

30. Mesolophid of m3:

(0) long, reaching the border of the molar; (1) of medium length, about half the distance between the longitudinal ridge and lingual border; (2) short, or absent 
Bull. Min. Res. Exp. (2016) 152:85-119

\section{PLATE}




\section{PLATE I}

C. fikreti n. sp. from Dededağ:

a: M1 (holotype), DD-1;

b: M2, DD-11;

c: M3, DD-21;

d: m1, DD-31;

e: m2, DD-41;

f: m3, DD-51 
Bull. Min. Res. Exp. (2016) 152:85-119

PLATE I
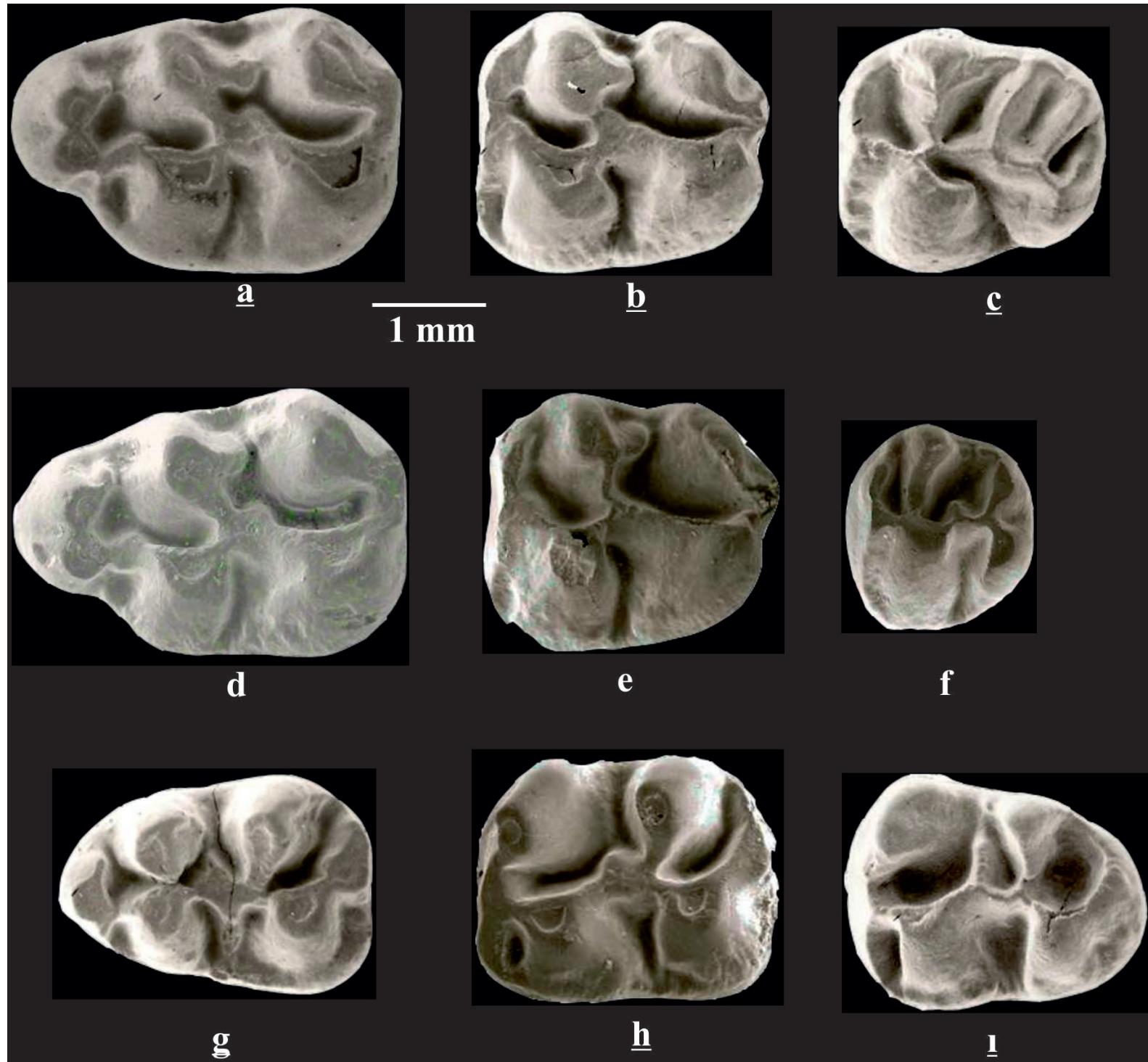


\section{PLATE II}

C. fikreti n. sp. from Dededağ:

a: M1 (holotype), DD-1;

b: M2, DD-11;

c: M3, DD-21;

d: m1, DD-31;

e: m2, DD-41;

f: m3, DD-51 
Bull. Min. Res. Exp. (2016) 152:85-119

\section{PLATE II}
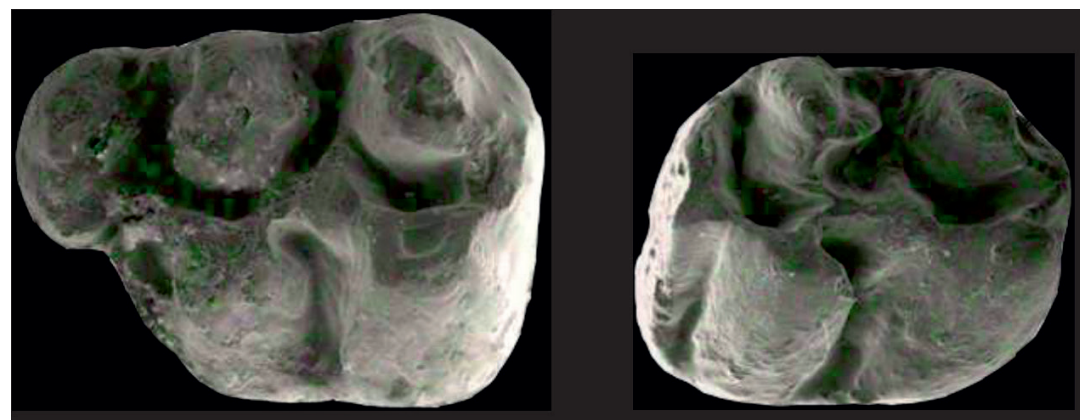

b

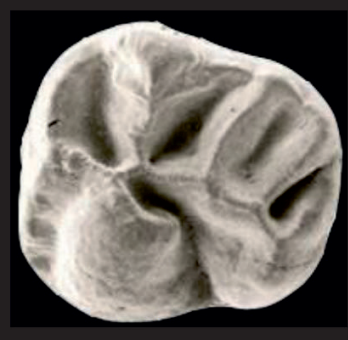

c

\section{$1 \mathrm{~mm}$}
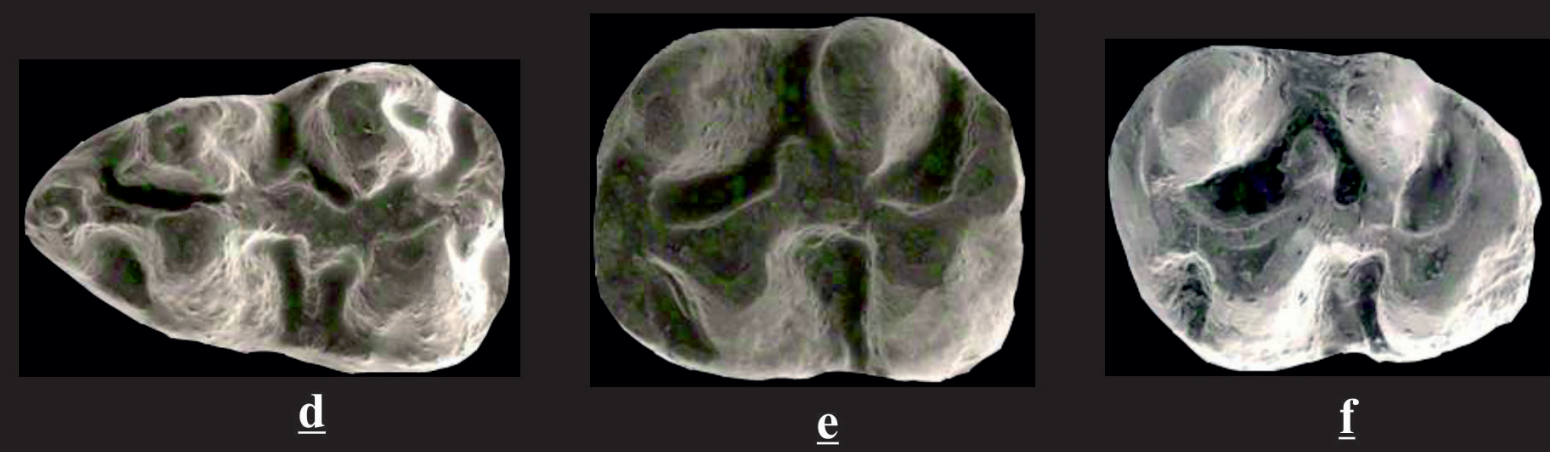


\section{PLATE III}

C. yapintiensis $\mathrm{n}$. sp. from Yapıntı:

a: M1 (holotype), YP-121;

b: M2, YP-133;

c: M3, YP-141;

d: M2, YP-131;

e: m1, YP-151 
Bull. Min. Res. Exp. (2016) 152:85-119

PLATE III

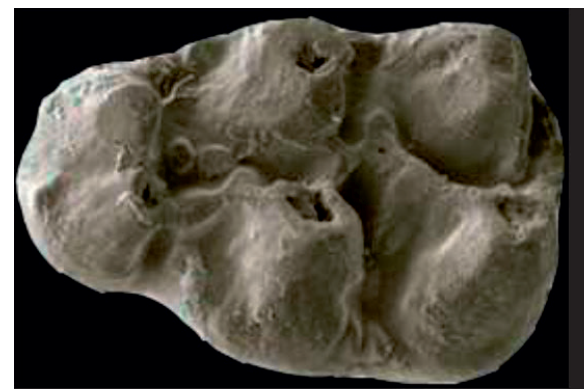

a

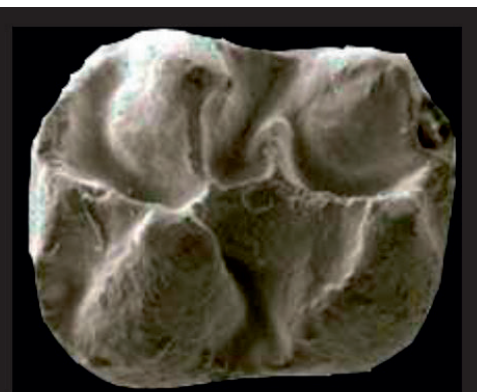

b

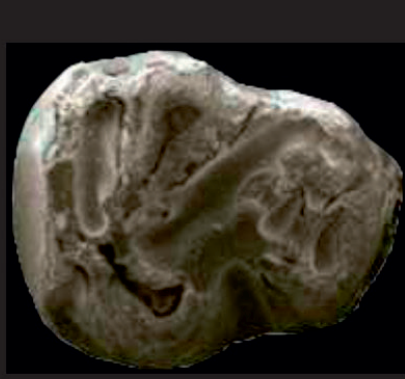

c
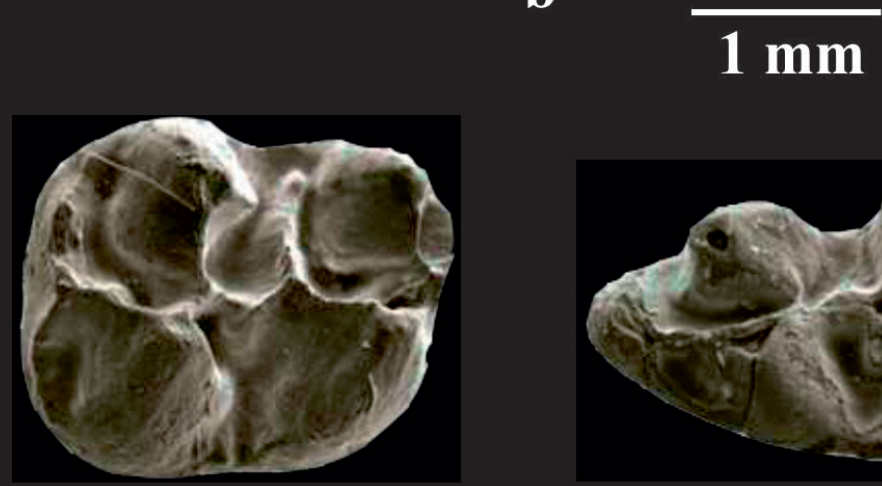

d

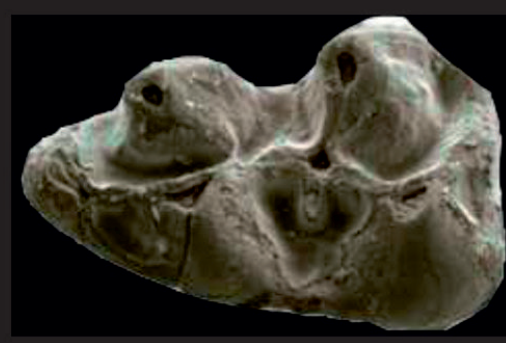

e 


\section{PLATE IV}

C. kasapligili from Yapıntı:

a: M1, YP-9;

b: M2, YP-33;

c: M3, YP-47;

d: m1, YP-74;

e: m2, YP-89;

f: m3, YP-104 
Bull. Min. Res. Exp. (2016) 152:85-119

PLATE IV

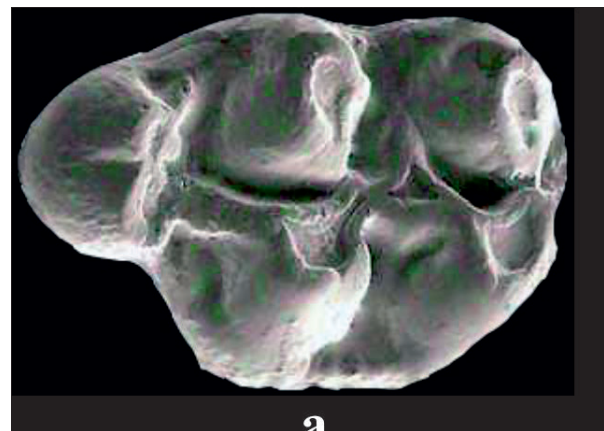

$\mathbf{a}$

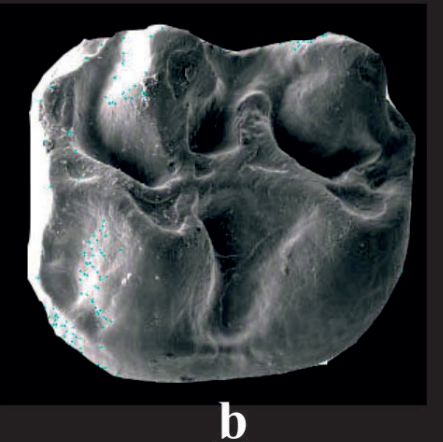

$1 \mathrm{~mm}$

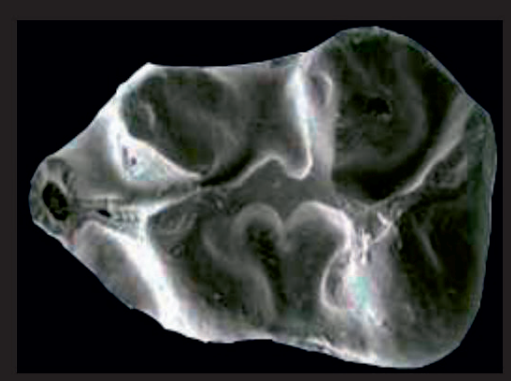

d

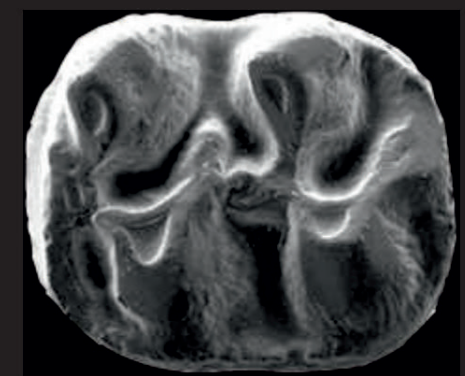

$\underline{\mathbf{e}}$

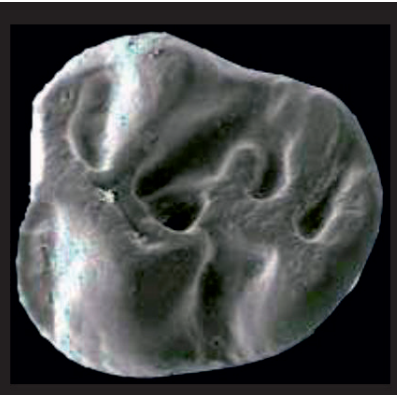

$\underline{\mathbf{c}}$

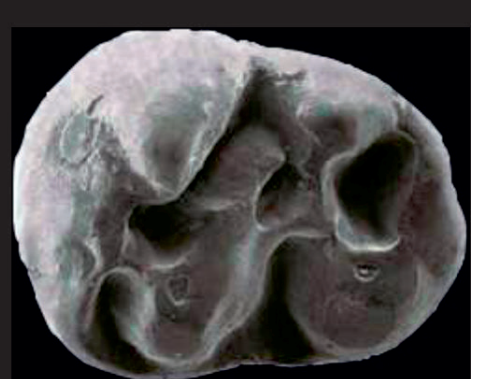

f 


\section{PLATE V}

C. cf. kasapligili from Harta:

a: M1, HT-82;

b: M2, HT-86;

c:M3, HT-89;

d: m1, HT-91;

e: m2, HT-95;

f: m3, HT-100 
Bull. Min. Res. Exp. (2016) 152:85-119

PLATE V

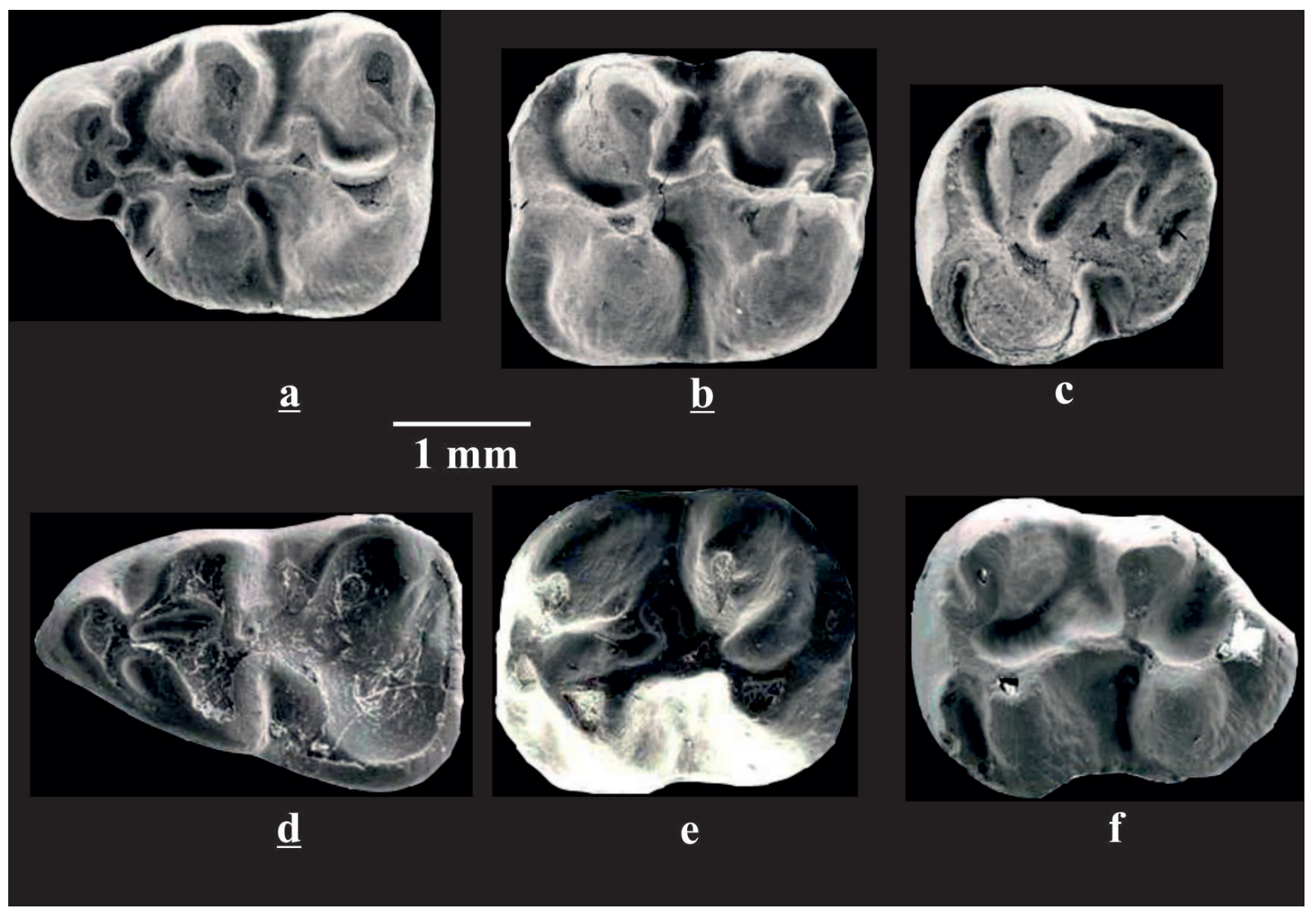




\section{PLATE VI}

C. magnesiensis n. sp. from Kınık:

a: M1 (holotype), KN-101;

b:M2, KN-111;

c: M3, KN-142;

d: m2, KN-171;

e: $\mathrm{m} 3, \mathrm{KN}-201$ 
Bull. Min. Res. Exp. (2016) 152:85-119

PLATE VI

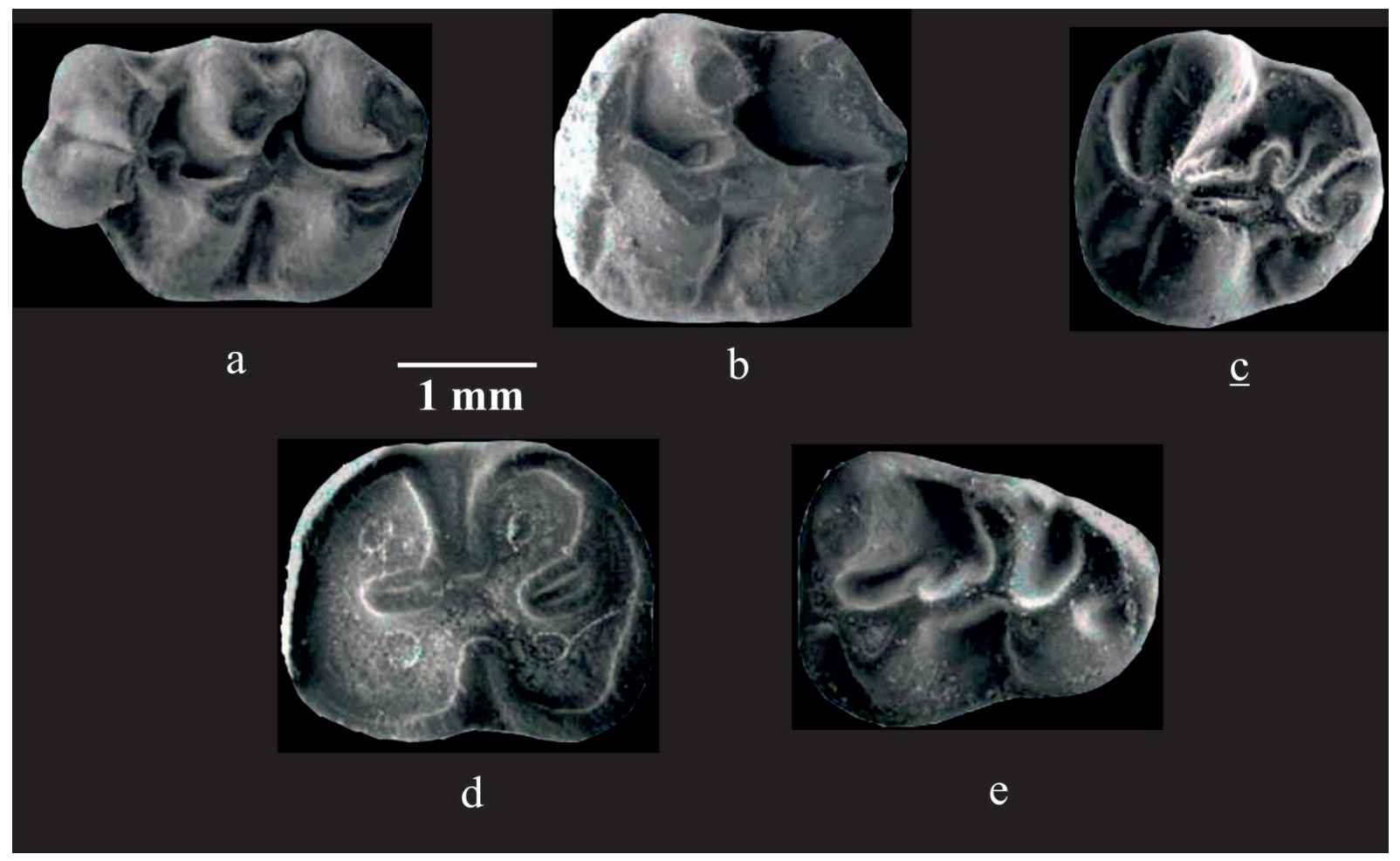




\section{PLATE VII}

C. versteegi from Kınık:

a: M1, KN-105;

b: M2, KN-123;

c: M3, KN-144;

d: m1, KN-163;

e: $\mathrm{m} 2, \mathrm{KN}-173$;

f: m3, KN-191 
Bull. Min. Res. Exp. (2016) 152:85-119

\section{PLATE VII}

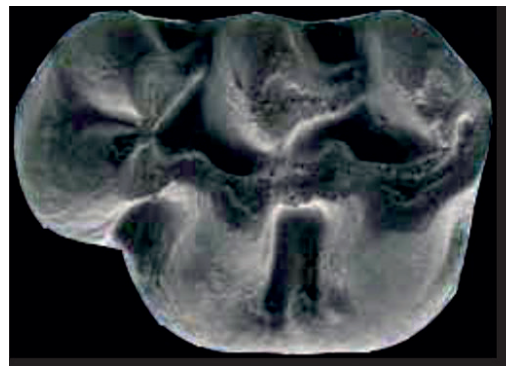

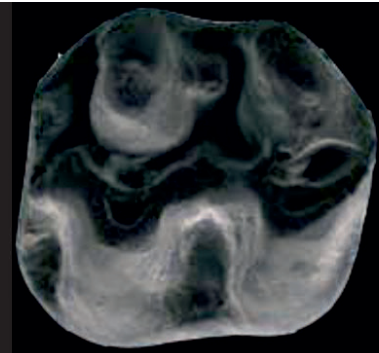

b

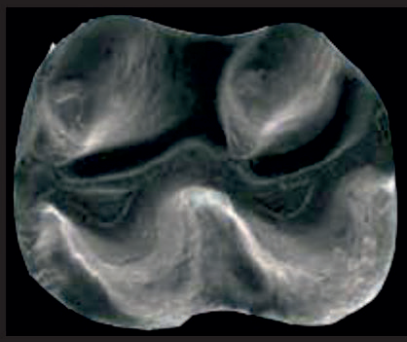

$\underline{\mathrm{d}}$

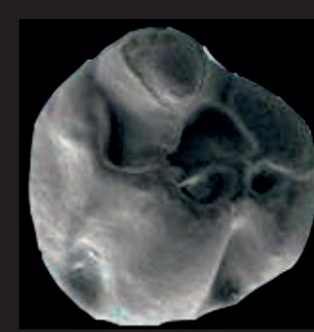

c

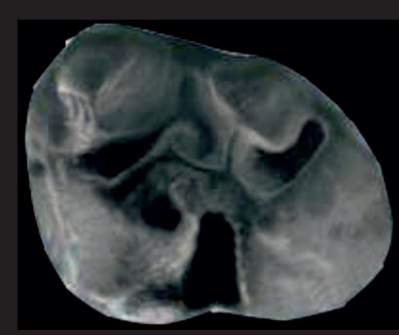

f 


\section{PLATE VIII}

Deperetomys cf. intermedius from Kınık:

a: M1, KN-1;

b: M2, KN-11 
Bull. Min. Res. Exp. (2016) 152:85-119

PLATE VIII

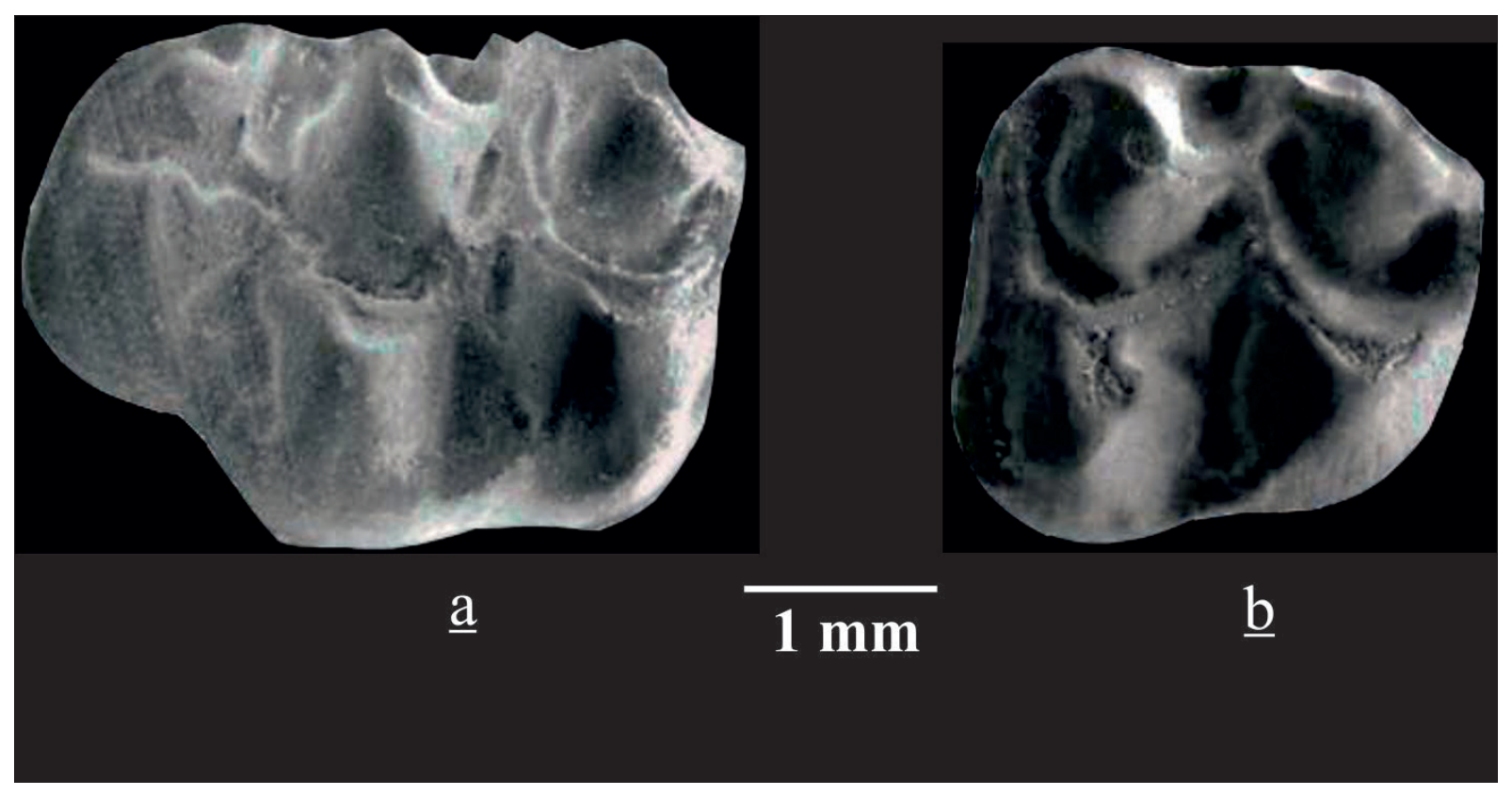


